\title{
High efficiency electric power generation: The environmental role
}

\author{
János M. Beér* \\ Massachusetts Institute of Technology, Room 66-301, Cambridge, MA 02139, USA
}

Received 31 March 2006; accepted 3 August 2006

Available online 17 October 2006

\begin{abstract}
Electric power generation system development is reviewed with special attention to plant efficiency. It is generally understood that efficiency improvement that is consistent with high plant reliability and low cost of electricity is economically beneficial, but its effect upon reduction of all plant emissions without installation of additional environmental equipment, is less well appreciated. $\mathrm{As}_{\mathrm{CO}_{2}}$ emission control is gaining increasing acceptance, efficiency improvement, as the only practical tool capable of reducing $\mathrm{CO}_{2}$ emission from fossil fuel plant in the short term, has become a key concept for the choice of technology for new plant and upgrades of existing plant. Efficiency is also important for longer-term solutions of reducing $\mathrm{CO}_{2}$ emission by carbon capture and sequestration (CCS); it is essential for the underlying plants to be highly efficient so as to mitigate the energy penalty of CCS technology application. Power generating options, including coal-fired Rankine cycle steam plants with advanced steam parameters, natural gas-fired gas turbine-steam, and coal gasification combined cycle plants are discussed and compared for their efficiency, cost and operational availability. Special attention is paid to the timeline of the various technologies for their development, demonstration and commercial availability for deployment.
\end{abstract}

(C) 2006 Elsevier Ltd. All rights reserved.

Keywords: Electric power generation; Efficiency; Environment; $\mathrm{CO}_{2}$ emission; Costs

\section{Contents}

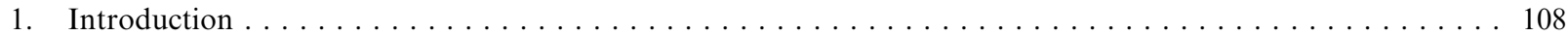

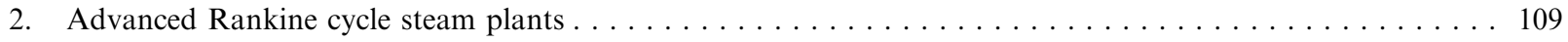

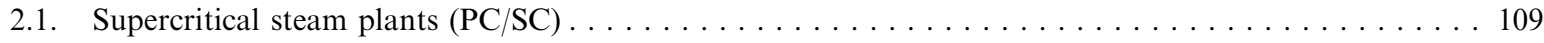

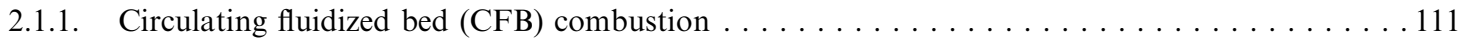

\footnotetext{
Abbreviations: ASC, advanced supercritical; ASU, air separation unit; bar, $10^{5} \mathrm{~Pa}=0.1 \mathrm{MPa}=10^{5} \mathrm{~N} / \mathrm{m}^{2}\left(\mathrm{~m}^{-1} \mathrm{~kg} \mathrm{~s}{ }^{-2}\right)=14.5 \mathrm{psi}$; CCS, $\mathrm{CO}_{2}$ capture and sequestration; $\mathrm{CF}$, capacity factor \%; CFBC, circulating fluidized bed combustor; EFOR, planned + forced outages; FGR, flue gas recycle; HHV, higher heating value; IEA, International Energy Agency; IGCC, integrated gasification combined cycle; ITM, ion transport membrane; LHV, lower heating value; MASB, multi annular swirl combustor; NG, natural gas; NGCC, natural gas combined cycle; Oxy/FGR, oxygen blown combustion with flue gas recycle; PFBC, pressurized fluidized bed combustor; SC, supercritical (steam); SI, international system unit; SOFC, solid oxide fuel cell; TC, topping combustor; USC, ultra supercritical (steam)

*Tel.: +617253 6661; fax: + 6172532272.

E-mail address: jmbeer@mit.edu.
} 


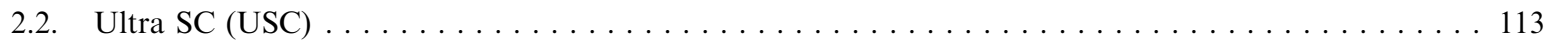

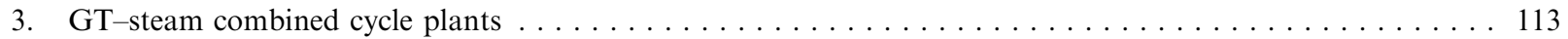

3.1. Natural gas-fired combined cycle plants (NGCC) $\ldots \ldots \ldots \ldots \ldots \ldots$

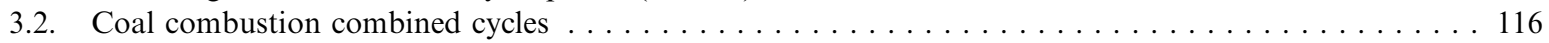

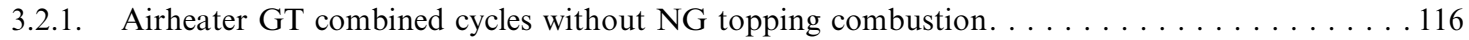

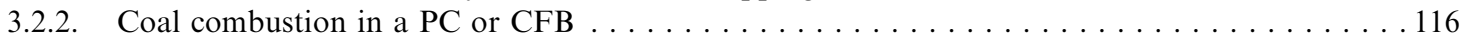

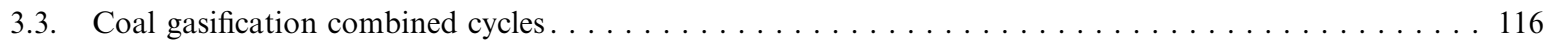

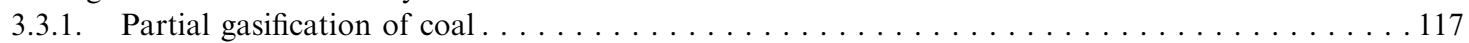

3.3.2. Integrated gasification combined cycle (IGCC) $\ldots \ldots \ldots \ldots \ldots \ldots$

3.4. Hybrid gasification-fuel cell $-\mathrm{GT}-\mathrm{steam}$ combined cycles . . . . . . . . . . . . . . . . . . 127

3.4.1. The DOE's Vision21 cycle [40] (in the DOE R\&D portfolio) . . . . . . . . . . . . . . . . . . . . . . . . . . . . . . .

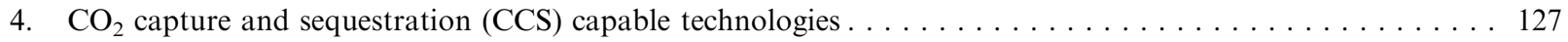

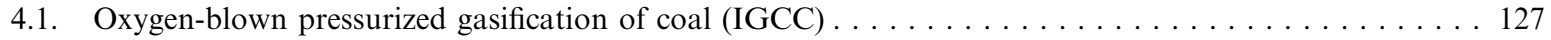

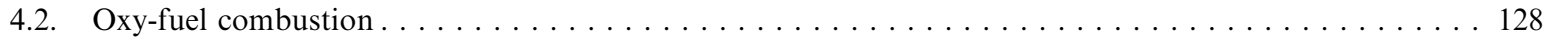

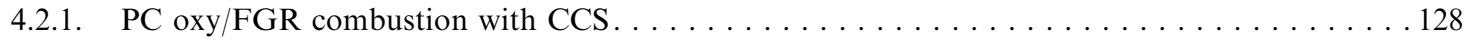

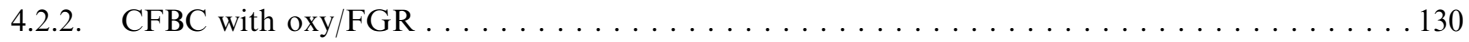

4.3. Chemical and thermal looping (in the DOE R\&D portfolio) . . . . . . . . . . . . . . . 130

5. Efficiency, $\mathrm{CO}_{2}$ emissions and cost of clean coal power generation technologies $\ldots \ldots \ldots \ldots 131$

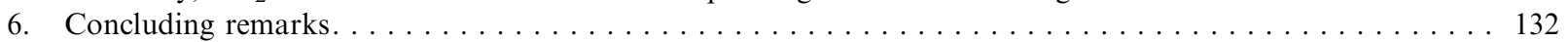

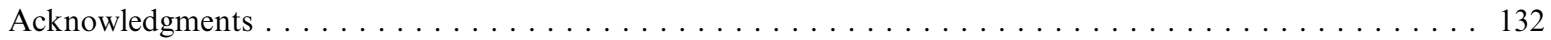

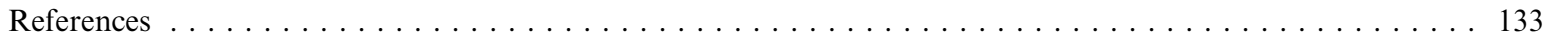

\section{Introduction}

Efficiency $(\eta \%)$, the electric energy output as a fraction of the fuel energy input of a thermal power plant is usually expressed in percentages. Another parameter used for determining efficiency is the heat rate $(\mathrm{HR})$, the fuel energy input required for the generation of unit of electricity $(\mathrm{Btu} / \mathrm{kWh})$, or $(\mathrm{kJ} /$ $\mathrm{kWh})$. Generation efficiency $(\eta \%)$ is $3600(\mathrm{~kJ} / \mathrm{kWh})$ divided by $\mathrm{HR}(\mathrm{kJ} / \mathrm{kWh}) \times 100$, or $3414 \mathrm{Btu} / \mathrm{kWh}$ divided by $\mathrm{HR}(\mathrm{Btu} / \mathrm{kWh}) \times 100$. The fuel energy input can be entered into the calculation either by the higher (gross) or by the lower(net) heating value of the fuel (HHV or LHV); but when comparing the efficiency of different energy conversion systems, it is important to ensure that the same type of heating value is used.

$\mathrm{HHV}$ is the heating value directly determined by calorimetric measurement in the laboratory. In this measurement, the fuel is combusted in a closed vessel, and the heat of combustion is transferred to water that surrounds the calorimeter. The combustion products are cooled to $60^{\circ} \mathrm{F}\left(15^{\circ} \mathrm{C}\right)$ and hence, the heat of condensation of the water vapor originating from the combustion of hydrogen, and from the evaporation of the coal moisture, is included in the measured heating value. For determining the lower heating value, LHV, calculation is needed to deduct the heat of condensation from the HHV. In US engineering practice, HHV is generally used for steam plants, while in the European practice, efficiency calculations are based on LHV. For gas turbine (GT) cycles, LHV is usually used both in the US and Europe. As an exception, HHV is often used for IGCC plants in the US so that comparison with other coal technology be consistent. Perhaps one reason for this difference in the method of calculating steam power plant efficiencies is that US electric utilities purchase coal on a $\$$ MBtu (HHV) basis and want to know their efficiency also on that basis, while the European practice is based on the realization that the heat of condensation is not a recoverable part of the fuel's energy, because it is not practicable to cool sulfurbearing flue gas to below its dew point in the boiler.

LHV can be calculated by using the International Energy Agency (IEA) formula as LHV $=\mathrm{HHV}-$ $\left(91.14 \times \mathrm{H}+10.32 \times \mathrm{H}_{2} \mathrm{O}+0.35 \times \mathrm{O}\right)$, where $\mathrm{LHV}$ and $\mathrm{HHV}$ are in $\mathrm{Btu} / \mathrm{lb}$, and $\mathrm{H}, \mathrm{H}_{2} \mathrm{O}$ and $\mathrm{O}$ are in $\%$, on "as received" basis. [1] or in SI units as $\mathrm{LHV}=\mathrm{HHV}-\left(0.2121 \times \mathrm{H}+0.02442 \times \mathrm{H}_{2} \mathrm{O}+\right.$ $0.0008 \times \mathrm{O}$ ), where $\mathrm{LHV}$ and $\mathrm{HHV}$ are in $\mathrm{MJ} / \mathrm{kg}$, and $\mathrm{H}, \mathrm{H}_{2} \mathrm{O}$ and $\mathrm{O}$ are in $\%$. For better comparisons with non US data, unless specifically stated, LHV-based efficiency values are given in the following discussion.

Reference is made often to changes in efficiency by percentage points, which should be distinguished from relative changes in percentage; for example, a change by two percentage points from $40 \%$ to $42 \%$ is 
a relative change of $5 \%$. The difference in efficiency between HHV and LHV for bituminous coal is about 2 percentage points absolute (5\% relative), but for high-moisture sub bituminous coals and lignites the difference is about 3-4 percentage points $(>8 \%$ relative). The average efficiency of US installed coalbased electricity generating plant is about $34 \%$ (LHV).

Advanced cycles of power generation, some of which are mature technologies, others, at the stage of $\mathrm{R} \& \mathrm{D}$ or demonstration, promise to generate electricity at significantly higher efficiency, up to $50 \%$ (LHV). Higher efficiency which is presently the practical route to mitigating $\mathrm{CO}_{2}$ emission is also key to the reduction of all emissions. In the near and medium term, there are several options for clean and more efficient electric power generation including the following technologies:

Advanced Rankine cycle plants

- Pulverized coal (PC) combustion in SC boiler (PC/SC) with steam parameters: 245 bar, 565/ $565 / 565^{\circ} \mathrm{C}\left(1050 / 1050 / 1050{ }^{\circ} \mathrm{F}\right)$.

- PC combustion in ultra SC boiler (PC/USC) with steam parameters: 300 bar $600 / 600{ }^{\circ} \mathrm{C},(4350 \mathrm{psi}$, $\left.1100 / 1100^{\circ} \mathrm{F}\right)$.

- Ultra SC (PC/USC) 375 bar, $700 / 720^{\circ} \mathrm{C}$ (5440 psi, $\left.1292 / 1328^{\circ} \mathrm{F}\right)$.

- Circulating fluidized bed combustion (CFBC) in SC boiler.

Brayton-Rankine combined cycle plants

- Natural gas combined cycle (NGCC).

- Pressurized fluidized bed (PFBC) with topping combustion cycle (TC).

- Integrated gasification combined cycle (IGCC).

- Hybrid gasification/fuel cell/GT/steam cycle (DOE's Vision21 cycle).

Carbon capture and sequestration (CCS) capable plants

- IGCC with $\mathrm{CO}_{2}$ capture and compression.

- PC/SC with oxy-flue gas recirculation $\left(\mathrm{O}_{2} / \mathrm{FGR}\right)$

- CFBC with $\mathrm{O}_{2} / \mathrm{FGR}$.

- Coal gasification with chemical and thermal looping.

\section{Advanced Rankine cycle steam plants}

PC combustion in a Rankine steam cycle has been the prevailing mode of coal utilization in power generation world wide, since the 1920s. Today, typical subcritical steam operating parameters are $163 \mathrm{bar} / 538^{\circ} \mathrm{C}\left(2400 \mathrm{psig} / 1000^{\circ} \mathrm{F}\right)$ with single reheat to $538^{\circ} \mathrm{C}\left(1000^{\circ} \mathrm{F}\right)$. Efficiency of subcritical steam plant with steam parameters 168 bar 538/ $538^{\circ} \mathrm{C}\left(2469 \mathrm{psi}, 1000 / 1000^{\circ} \mathrm{F}\right)$ can reach about $40 \%$ (LHV).

\subsection{Supercritical steam plants $(P C / S C)$}

$\mathrm{PC} / \mathrm{SC}$ have been in use since the 1930s, mainly in Europe, and since the 1960s sporadically also in the US, but improvements in materials, and increasing demand for higher efficiency are making this system presently the choice of new coal-fired utility plant world wide. A schematic of advanced PC-fired forced circulation boiler equipped with scrubbers for flue gas desulfurization (FGD) and selective catalytic reactor (SCR) for deep reduction of $\mathrm{NO}_{x}$ is shown in Fig. 1 [1].

The efficiency of $\mathrm{PC} / \mathrm{SC}$ power plant can be increased in small steps to $45 \%$ (LHV) and beyond, as illustrated by Schilling [2] in Fig. 2. The first two steps in the diagram concern the waste gas heat loss, the largest of a boiler's heat losses, about $6-8 \%$.

The air ratio, usually called excess air factor, represents the mass flow rate of the combustion air as a multiple of the theoretically required air for complete combustion. The excess air increases the boiler exit-gas mass flow and, hence, the waste gas heat loss. Improved combustion technology, e.g., finer coal grinding and improved burner design, permit lowering the excess air without sacrificing completeness of combustion. Some of these remedies require additional expenditure in energy, e.g., for finer coal grinding, and for increasing the momentum flux of the combustion air through the burners, but this increase in parasitic energy is usually small compared to the efficiency gain due to the reduced excess air.

The boiler exit gas temperature can be reduced by appropriate boiler design limited only by the dew point of the flue gas. There is a close relationship between the excess air of combustion and the low limit of exit gas temperature from a boiler fired by a sulfur bearing fuel. Higher excess air leads to an increase in the oxidation of $\mathrm{SO}_{2}$ to $\mathrm{SO}_{3}$, with $\mathrm{SO}_{3}$ promoting sulfuric acid formation in the combustion products. Sulfuric acid vapor increases the dew point of the flue gas and hence raises the permissible minimum exit gas temperature. At an exit gas temperature of $130{ }^{\circ} \mathrm{C}\left(266^{\circ} \mathrm{F}\right)$ a reduction of every 


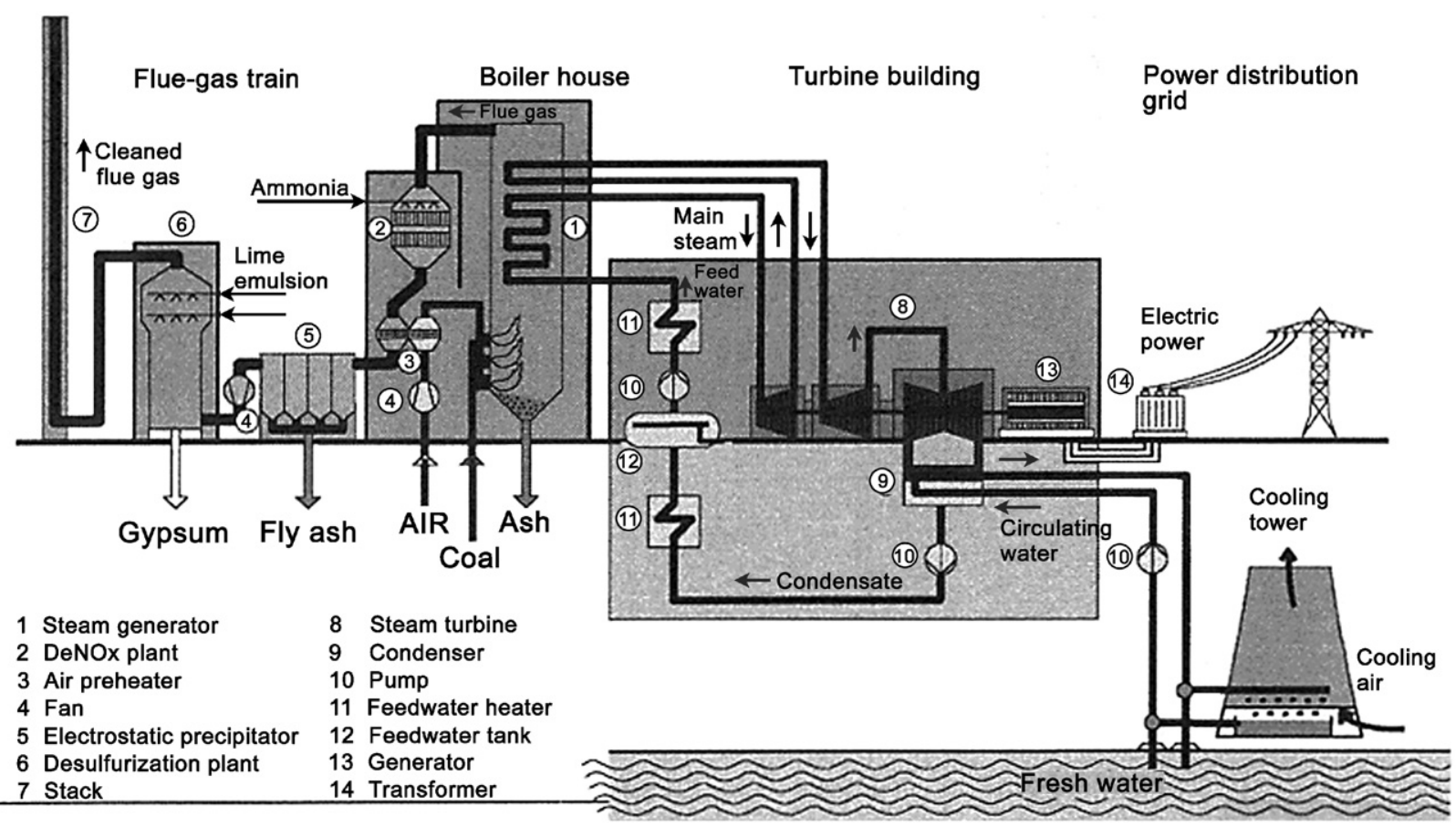

Fig. 1. Advanced pulverized coal-fired power plant [1].

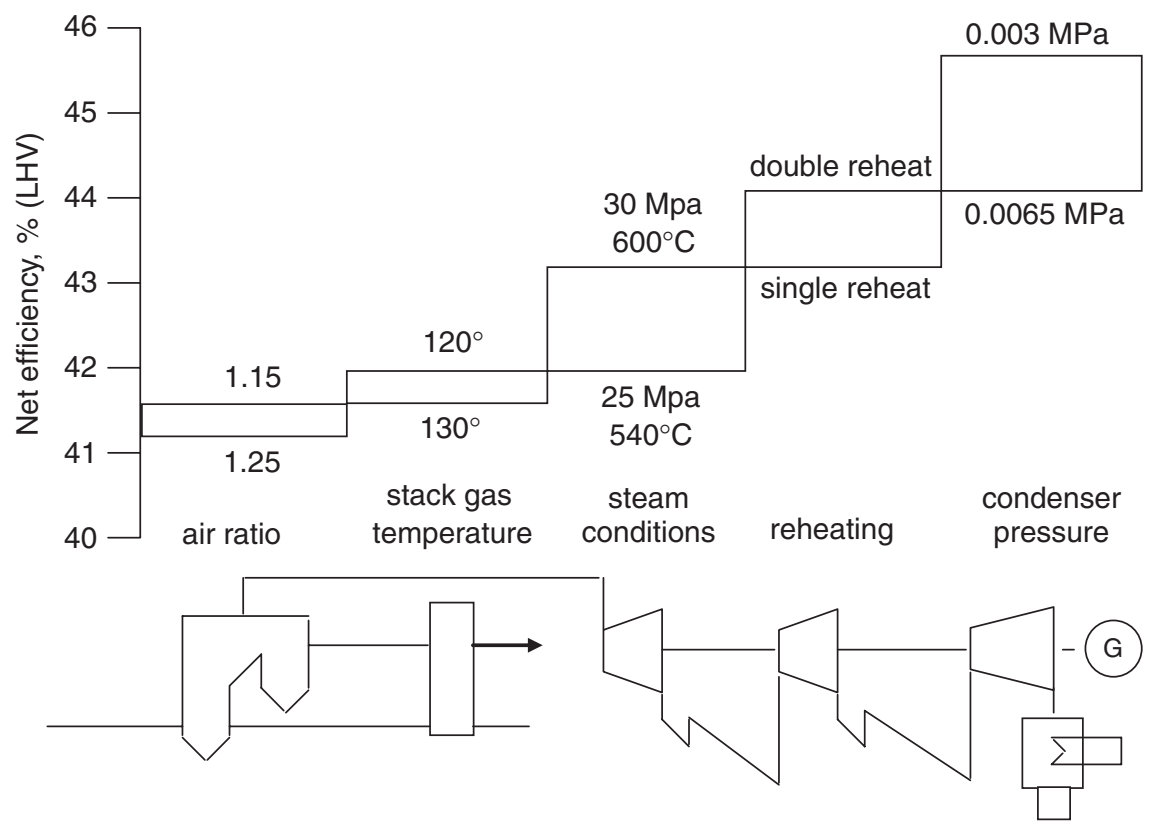

Fig. 2. Effect of various measures for improving the efficiency (LHV) of pulverized coal-fired power generating plant [2]

$10{ }^{\circ} \mathrm{C}\left(18^{\circ} \mathrm{F}\right)$ in boiler exit temperature increases the plant efficiency by about $0.3 \%$.

The Rankine cycle efficiency is proportional to the pressure and temperature of heat addition to the cycle, and is inversely proportional to the condenser pressure, and therefore to the temperature of the cooling medium. The usual design basis for condenser pressure in the US is $2.0^{\prime \prime} \mathrm{Hg}$ abs. 
(67 mbar). Power plants in Northern Europe with access to lower-temperature cooling water use condenser pressure of $1.0^{\prime \prime} \mathrm{Hg}$ abs. (30 mbar) pressure. This difference can produce an efficiency gain of more than 2 percentage points.

\subsubsection{Circulating fluidized bed (CFB) combustion}

In fluidized combustion coal is combusted in a hot bed of sorbent particles that are suspended in motion (fluidized) by combustion air that is blown in from below through a series of nozzles. CFB is the most common fluidized combustion design today. CFB operates at gas velocities high enough to entrain a large portion of the solids $(4-10 \mathrm{~m} / \mathrm{s}$ $\sim 12-30 \mathrm{ft} / \mathrm{s}$ ), which then is separated from the flue gas and recycled (recirculated) to the lower furnace to achieve good carbon burnout and $\mathrm{SO}_{2}$ sorbent utilization. Typically, an external hot cyclone is used at the furnace exit as a separation device.

For $\mathrm{SO}_{2}$ capture, limestone is fed into the fluidized bed in addition to crushed coal. The limestone is converted to free lime, a portion of which reacts with the $\mathrm{SO}_{2}$ to form calcium sulfate. At steady-state operation, the bed consists of unburned fuel, limestone, free lime, calcium sulfate and ash. Because of the well-mixed nature of the bed and the relatively long residence time of the fuel particles (via high recycle rates in the CFB), efficient combustion can be maintained at temperatures as low as $843-899^{\circ} \mathrm{C}\left(1550-1650{ }^{\circ} \mathrm{F}\right)$. This combustion is the optimum temperature range for in-situ capture of $\mathrm{SO}_{2}$ by the free lime.

The environmental performance of FBC compared to PC boilers is enhanced by the inherently lower $\mathrm{NO}_{x}$ production due to the relatively low combustion temperatures of the fluidized combustion process. Staging the combustion air and decreasing the overall excess air level also reduces $\mathrm{NO}_{x}$ production. Emissions are typically in the range of $0.05-0.20 \mathrm{lb} / \mathrm{MBtu}\left(36-145 \mathrm{ppm}\right.$ at $\left.3 \% \mathrm{O}_{2}\right)$ without post-combustion $\mathrm{NO}_{x}$ controls, compared to $0.20-0.40 \mathrm{lb} / \mathrm{MBtu}\left(145-290 \mathrm{ppm}\right.$ at $\left.3 \% \mathrm{O}_{2}\right)$ for new PC boilers with the latest low- $\mathrm{NO}_{x}$ burners and over-fire air. The use of relatively inexpensive selective non-catalytic reduction (SNCR) systems with CFB can reduce the flue gas $\mathrm{NO}_{x}$ level an additional $50-90 \%$, depending on ammonia slip and detached plume considerations. With a PC boiler, the more expensive SCR system would probably be required to achieve the same flue gas $\mathrm{NO}_{x}$ levels as FBC with SNCR. However, the low combustion temperature does have some disadvantages. CFB boilers emit higher levels of $\mathrm{N}_{2} \mathrm{O}$, which forms and survives at temperatures below $1094{ }^{\circ} \mathrm{C}\left(2000{ }^{\circ} \mathrm{F}\right)$. $\mathrm{N}_{2} \mathrm{O}$ is a greenhouse gas with a global warming potential 296 times that of $\mathrm{CO}_{2}$. Because of its low concentration in the flue gas (typically in the range of $40-70 \mathrm{ppm}$ at $3 \% \quad \mathrm{O}_{2}$ ) this $\mathrm{N}_{2} \mathrm{O}$ emission corresponds to an equivalent $15 \%$ increase in $\mathrm{CO}_{2}$ emissions. A more detailed discussion of $\mathrm{N}_{2} \mathrm{O}$ emissions from $\mathrm{FBC}$ has been presented in the May 2003 NCC Report "Coal Related Greenhouse Gas Management Issues" [66].

Currently, the largest CFB unit in operation is $320 \mathrm{MW}$, but designs for units up to $600 \mathrm{MW}$ have been developed by three of the major CFB suppliers. Some of these designs are based on SC steam conditions. Because of the relatively low combustion temperature, $\mathrm{CFB}$ is not practicable with USC steam designs of higher than $550{ }^{\circ} \mathrm{C}$ $\left(1022^{\circ} \mathrm{F}\right)$ superheat or reheat temperatures.

As steam pressure and temperature are increased to beyond 221 bar (3208 psi) and $374.5^{\circ} \mathrm{C}\left(706^{\circ} \mathrm{F}\right)$, the steam becomes supercritical, it does not produce a two phase mixture of water and steam, and it does not have a saturation temperature or an enthalpy range of latent heat. Instead, it undergoes gradual transition from water to vapor in the enthalpy range of $1977-2442 \mathrm{~kJ} / \mathrm{kg}$ (850-1050 Btu/lb) with corresponding changes in physical properties such as density and viscosity.

Use of supercritical steam (SC) increases the Rankine cycle efficiency due to the higher pressure and higher mean temperature of heat addition, as illustrated by the $T-s$ and $h-s$ diagrams of SC cycles with reheat by G. Büki [3] in Figs. 3 and 4 .

In the temperature-entropy $(T-S)$ diagram the area under the curve above the temperature of heat extraction (horizontal line) is proportional to the energy yield of the cycle. It can be seen that heat addition at higher temperature increases the cycle efficiency. The dotted lines represent mean temperatures of heat addition for the cases of without reheat, and with single and double reheat, respectively.

In order to avoid unacceptably high moisture content of the expanding steam at the low-pressure stages of the steam turbine (a condition favored by high initial steam pressure), the steam, after partial expansion in the turbine, is taken back to the boiler to be reheated. The enthalpy-entropy $(h-s)$ diagram includes lines representing constant moisture concentrations $(x)$ of the wet saturated steam. It can be seen that as a result of reheating the moisture content of the expanding steam is reduced. 


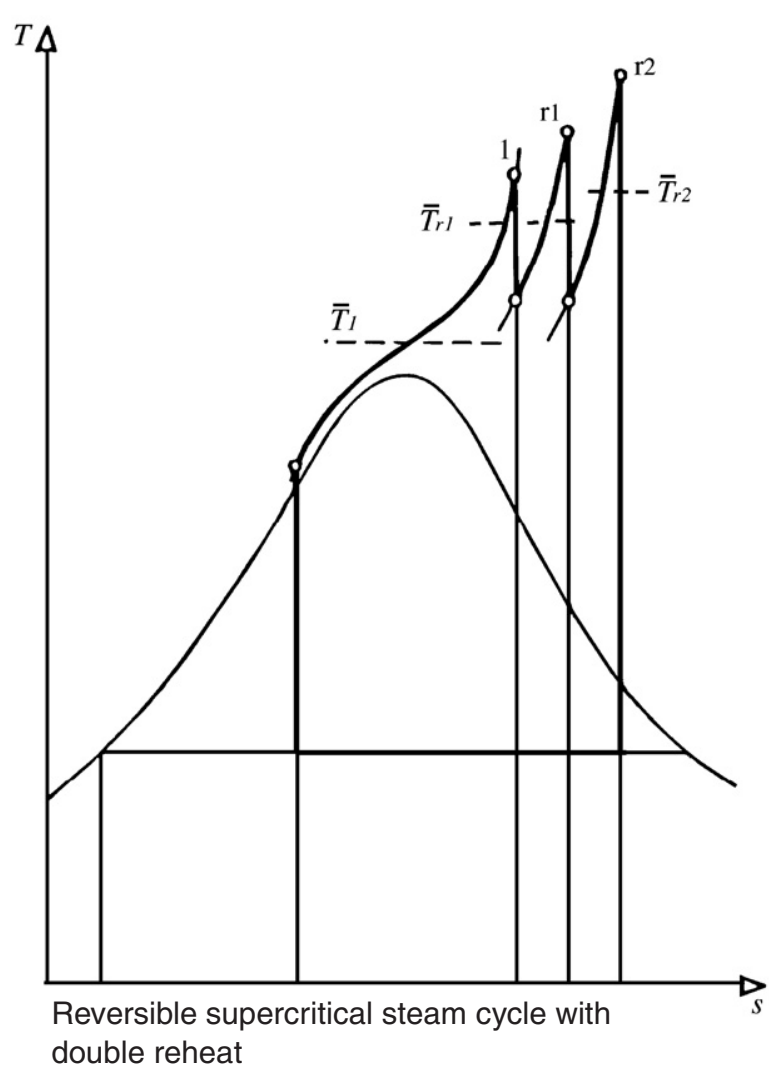

Fig. 3. Temperature-entropy $(T-s)$.

Reheat, single or double, also serves to increase the Rankine cycle efficiency because it raises the mean temperature of heat addition.

In the example shown in Fig. 4 [3], the expanding steam is returned once (a) or twice (b) from the turbine to the boiler for reheating to the same initial temperature of $580{ }^{\circ} \mathrm{C}$. It is usual, however, to reheat the steam to a higher than the original superheat temperature. Because of the lower steam pressure in the reheater, compared to the superheater, the reheater tube wall thickness can be reduced and, hence, a higher steam reheat-temperature can be reached without exceeding the permissible temperature of the tube's outer surface.

In subcritical pressure units, the steam is generated in systems of natural or forced circulation depending on the level of the steam pressure. At lower pressures, natural circulation can be used. Water at saturation temperature flows from the boiler-drum through unheated downcomer tubes, outside the boiler, and steam-water mixture rises to the boiler-drum through steam generating tubes that cover the fire side of furnace walls. In high-

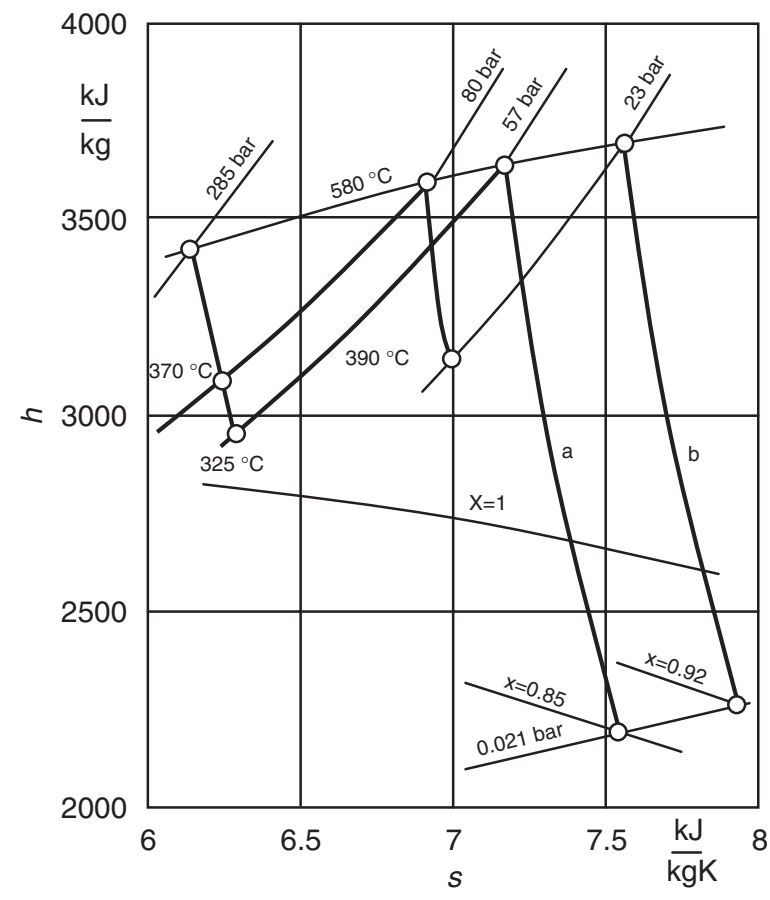

Supercritical steam turbine expansion lines a) single, and b) double reheat

Fig. 4. Enthalpy-entropy $(h-s)$ diagram representations of SC cycle with reheat [3].

pressure subcritical, and in supercritical oncethrough boilers, there is no boiler drum or water circulation; the boiler, instead, consists of a bundle of parallel tubing through which water is pumped. Along the length of the tubes heat is added in both the furnace and in the convective section of the boiler, the water gradually forms steam and is getting superheated at the outlet of the tubes. Because of lack of circulation, the tube length exposed to heat has to be increased. Spirally laid tube wall arrangements in the furnace and /or internally rifled tubes are the engineering response to this design concern [4]. Henry et al. [5], mention as an important benefit of spirally laid tubes around the furnace that as every tube forms part of all four walls, it acts as an integrator, minimizing the imbalance of heat absorption among the walls of the furnace.

Once-through units require high water purity because of lack of a boiler drum with blow down capability of the accumulated impurities. They also demand very well controlled and uniform volumetric heat release in the combustion chamber 
because the cooling of boiler tubes by SC occurs at lower heat transfer rates than that by nucleate boiling in subcritical steam.

Armor et al. EPRI [6], reviewed the performance and history of $\mathrm{PC} / \mathrm{SC}$ units in the US, and in Europe where most of the SC steam plants have been operating since the 1930 . There are about 160 $\mathrm{PC} / \mathrm{SC}$ plants in the US. These plants, most of which have been constructed in the 1970s, show efficiency advantages of about 2.9 points (between $41.5 \%$ (LHV) for SC, and $38.6 \%$ (LHV) for Sub C), amounting to a relative $7.5 \%$ over subcritical steam units, without increased outages, as shown in Fig. 5 [7].

There is renewed interest in SC steam plants today, mainly because of their reduced emissions on account of higher efficiency. SC parameters of 250 bar $(3625 \mathrm{psi}) 540^{\circ} \mathrm{C}\left(1000^{\circ} \mathrm{F}\right)$ single or double reheat with efficiencies of $41.5 \%$ (LHV) represent mature technology and are commercial in US boiler plant practice.

\subsection{Ultra $S C$ (USC)}

USC parameters of 300 bar and $600{ }^{\circ} \mathrm{C} / 600{ }^{\circ} \mathrm{C}$ $\left(4350 \mathrm{psi}, 1112^{\circ} \mathrm{F} / 1112^{\circ} \mathrm{F}\right)$ can be realized today, resulting in efficiencies of $45 \%$ (LHV) and higher, for bituminous coal fired power plants. There are several years of experience with these " $600{ }^{\circ} \mathrm{C}$ " plants in service, with excellent availability [8]. USC steam plants in service or under construction in Europe and in Japan during the last decade listed by Blum and Hald [8] are shown in Table 1. The improved efficiency represents a reduction of about $15 \%$ in the $\mathrm{CO}_{2}$ emission compared to the emission from installed capacity. Further improvement in efficiency achievable by higher USC parameters is dependent on the availability of new, high temperature alloys for boiler membrane wall, superheater and reheater tubes, thick-walled headers and steam turbines. Two major development programs in progress, the Thermie Project of the EC discussed by Kjaer et al. [9], and the Ultra-Supercritical Materials Consortium in the US by Palkes [10], aim at steam parameters of $375 \mathrm{bar}, 700^{\circ} \mathrm{C} / 720^{\circ} \mathrm{C}$ $\left(5439 \mathrm{psi}, \quad 1292^{\circ} \mathrm{F} / 1328^{\circ} \mathrm{F}\right.$ ), and 379 bar, $730^{\circ} \mathrm{C} /$ $760^{\circ} \mathrm{C} \quad\left(5500 \mathrm{psi}, \quad 1346^{\circ} \mathrm{F} / 1400^{\circ} \mathrm{F}\right)$, respectively. Henry et al. [5], provided the timeline of materials development and its relationship with advanced steam parameters as shown in Table 2. The plant efficiency increases by about one percentage point for every $20^{\circ} \mathrm{C}$ rise in superheat temperature. The graph adapted from Booras and Holt [11] in Fig. 6 illustrates the environmental effect of efficiency improvement.

It is anticipated that an advanced $700{ }^{\circ} \mathrm{C}$ $\left(1293^{\circ} \mathrm{F}\right)$ USC plant will be constructed during the next $7-10$ years constituting a benchmark for a $50 \%$ efficiency (LHV) coal-fired power plant resulting in $25 \%$ reduction in $\mathrm{CO}_{2}$, and all other emissions $[5,9]$.

\section{GT-steam combined cycle plants}

\subsection{Natural gas-fired combined cycle plants (NGCC)}

Because of the complementary temperature ranges of the Brayton GT cycle (1600-900 K) and the Rankine steam $(850-288 \mathrm{~K})$ cycle, their combination can produce significantly improved

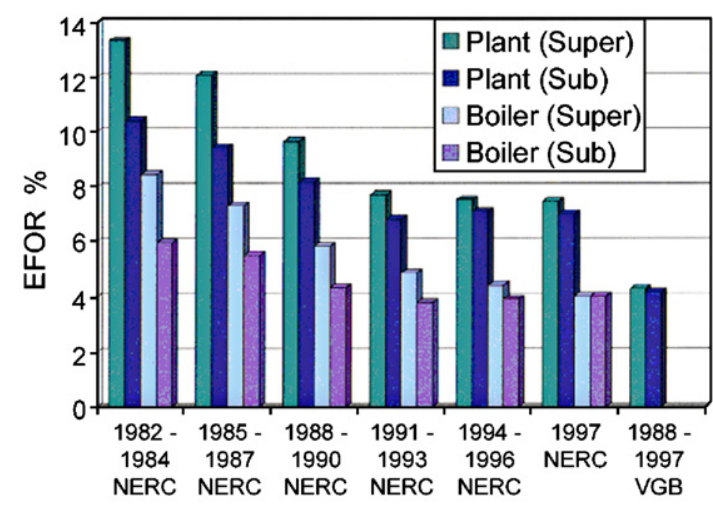

Studies to investigate differences in availability to subcritical/supercritical steam parameters:

- NERC-US (1989):

"Boiler tube failure trends"

- VGB-D (1988-97):

"Availability of thermal power plants"

Fig. 5. Comparison of availability of subcritical and supercritical PC plant [7]. 
Table 1

USC steam plants in service or under construction in Europe and in Japan [8]

\begin{tabular}{|c|c|c|c|c|c|c|c|}
\hline Power station & Cap. MW & Steam parameters & Fuel & $\begin{array}{l}\text { Year of } \\
\text { Comm }\end{array}$ & Eff. $\%$ & $\begin{array}{l}\text { Boiler/steam line } \\
\text { materials }\end{array}$ & $\begin{array}{l}\text { Turbine } \\
\text { materials }\end{array}$ \\
\hline Matsuura 2 & 1000 & $255 \mathrm{bar} / 598^{\circ} \mathrm{C} / 596^{\circ} \mathrm{C}$ & $\mathrm{PC}$ & 1997 & & Super304H/P91 & TMK1 \\
\hline Skærbæk 3 & 400 & $290 \mathrm{bar} / 580^{\circ} \mathrm{C} / 580^{\circ} \mathrm{C} / 580^{\circ} \mathrm{C}$ & NG & 1997 & 49 & TP347FG/P91 & COST $501 \mathrm{~F}$ \\
\hline Haramachi 2 & 1000 & $259 \mathrm{bar} / 604{ }^{\circ} \mathrm{C} / 602^{\circ} \mathrm{C}$ & $\mathrm{PC}$ & 1998 & & Super304H/P91 & HR1100 \\
\hline Nordjyiland 3 & 400 & $290 \mathrm{bar} / 5800^{\circ} \mathrm{C} / 580^{\circ} \mathrm{C} / 580^{\circ} \mathrm{C}$ & $\mathrm{PC}$ & 1998 & 47 & TP347FG/P91 & COST $501 \mathrm{~F}$ \\
\hline Nanaoota 2 & 700 & $255 \mathrm{bar} / 597^{\circ} \mathrm{C} / 595^{\circ} \mathrm{C}$ & $\mathrm{PC}$ & 1998 & & TP347FG/P91 & Toshiba $12 \mathrm{Cr}$ \\
\hline Misumi 1 & 1000 & $259 \mathrm{bar} / 604{ }^{\circ} \mathrm{C} / 602^{\circ} \mathrm{C}$ & $\mathrm{PC}$ & 1998 & & Super304H/HR3C/P91 & TMK2/TMK1 \\
\hline Lippendorf & 934 & $267 \mathrm{bar} / 554^{\circ} \mathrm{C} / 583^{\circ} \mathrm{C}$ & Lignite & 1999 & 42.3 & $1.4910 / \mathrm{p} 91$ & COST $501 \mathrm{E}$ \\
\hline Boxberg & 915 & $267 \mathrm{bar} / 555^{\circ} \mathrm{C} / 578^{\circ} \mathrm{C}$ & Lignite & 2000 & 41.7 & $1.4910 / \mathrm{p} 91$ & COST $501 \mathrm{E}$ \\
\hline Tsuruga 2 & 700 & $255 \mathrm{bar} / 597^{\circ} \mathrm{C} / 595^{\circ} \mathrm{C}$ & $\mathrm{PC}$ & 2000 & & Super304H/HR3C/P122 & Toshiba $12 \mathrm{Cr}$ \\
\hline $\begin{array}{l}\text { Tachibanawan } \\
2\end{array}$ & 1050 & $264 \mathrm{bar} / 605^{\circ} \mathrm{C} / 613^{\circ} \mathrm{C}$ & $\mathrm{PC}$ & 2001 & & Super304H/P122/P92 & TMK2/TMK1 \\
\hline Avedore 2 & 400 & $300 \mathrm{bar} / 580^{\circ} \mathrm{C} / 600^{\circ} \mathrm{C}$ & NG & 2001 & 49.7 & TP347FG/P92 & COST $501 \mathrm{E}$ \\
\hline Niederaussen & 975 & $265 \mathrm{bar} / 565^{\circ} \mathrm{C} / 600^{\circ} \mathrm{C}$ & Lignite & 2002 & $>43$ & TP347FG/E911 & COST $501 \mathrm{E}$ \\
\hline Isogo 1 & 600 & $280 \mathrm{bar} / 605^{\circ} \mathrm{C} / 613^{\circ} \mathrm{C}$ & PC & 2002 & & Super304H/P122 & COST $501 \mathrm{E}$ \\
\hline
\end{tabular}

Materials guide:

Superheater: TP347FG: Fine Grain 18Cr10NiMoNb, Super304H: 18Cr9Ni3Cu, HR3C: 25Cr20Ni, 14910: $18 \mathrm{Cr} 12 \mathrm{Ni} 2 \frac{1}{2} \mathrm{Mo}$.

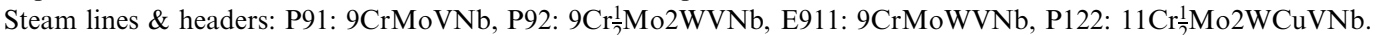

Turbine rotors: COST 501, F: 12CrMoVNbN101, COST $501 \mathrm{E}$ : 12CrMoWVNbN1011, HR1100: 111Cr1.2Mo0.4WVNbN.

TMK1: 10Cr1.5Mo0.2VNbN, TMK2: 10Cr0.3Mo2W0.2VNbN, Toshiba: 11Cr1Mo1WVNbN.

Table 2

Stages in materials development and related advanced steam parameters [5]

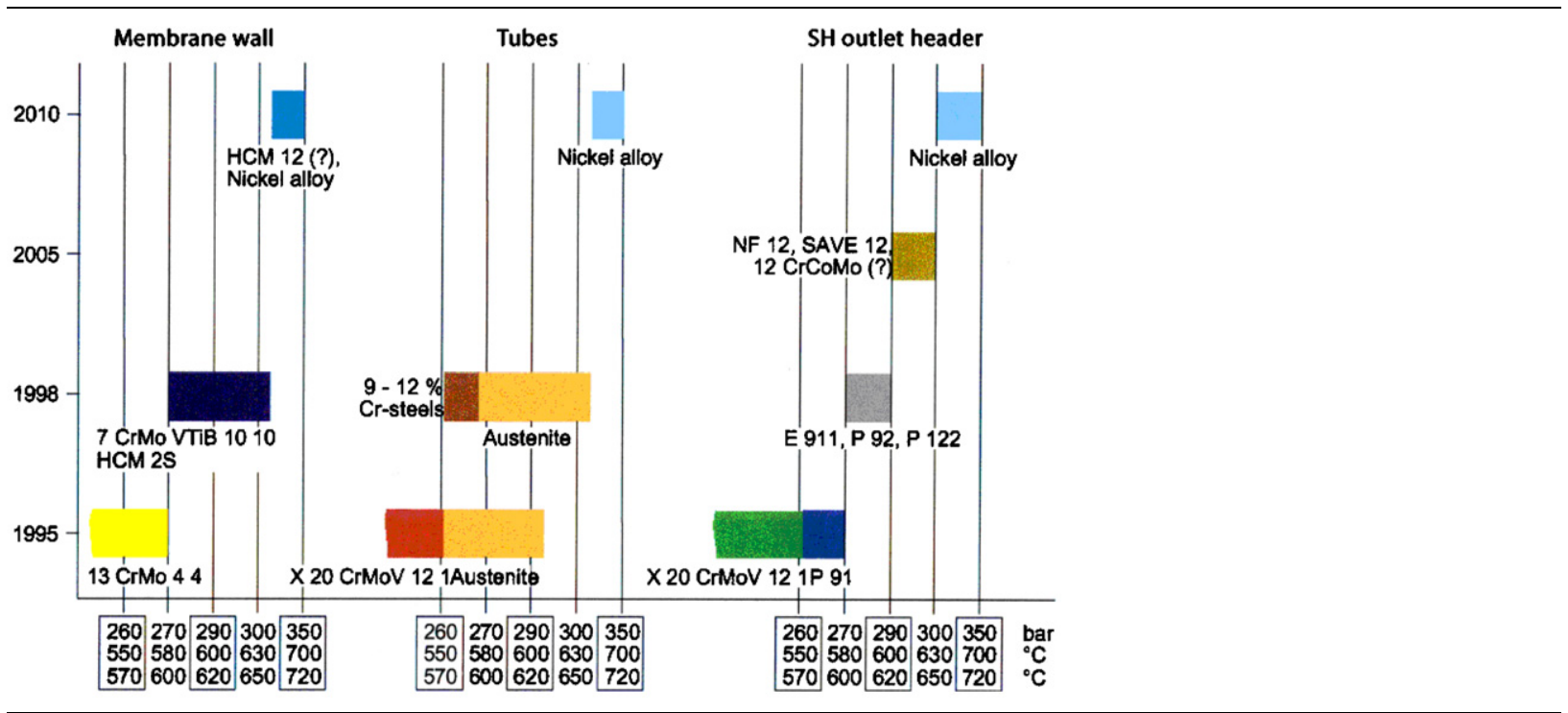

thermodynamic cycle efficiency, as shown by the $T-s$ diagram in Fig. 7.

Energy distribution in a combined cycle plant is illustrated in Fig. 8. Because of the major losses in the steam cycle (stack and condenser losses) the efficiency of the combined cycle improves with a larger part of the fuel's chemical energy converted in the GT cycle. Improved thermal coating and closed circuit steam cooling of turbine blades, and use of $\mathrm{N}_{2}$ instead of steam as diluent for reducing NO formation permits higher turbine firing temperatures to be attained. For about every $30^{\circ} \mathrm{C}$ 


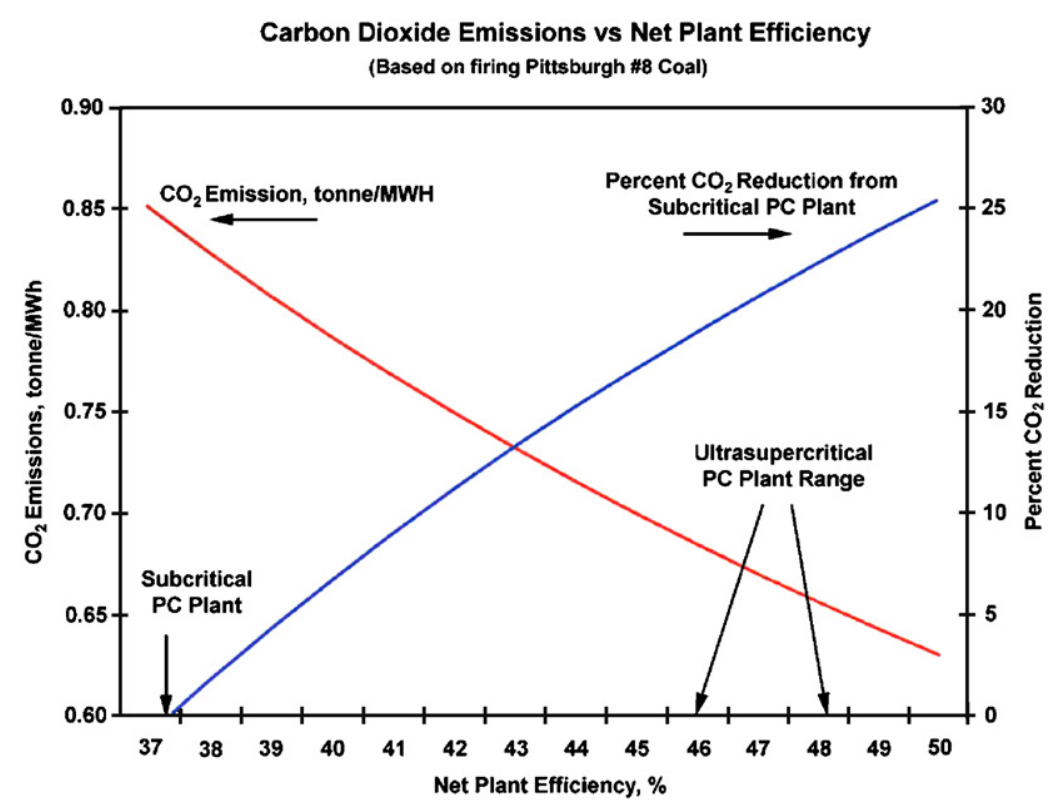

Fig. 6. $\mathrm{CO}_{2}$ emission vs. plant efficiency (HHV) [11].

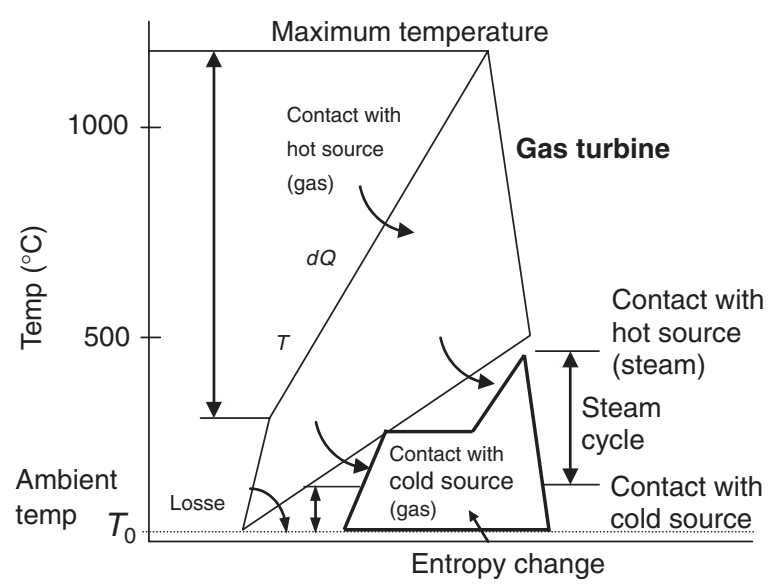

Fig. 7. $T-s$ diagram of gas turbine-steam combined cycle.

temperature rise in GT firing temperature, the combined cycle efficiency is increased by one percentage point so that a combined cycle efficiency of $60 \%$ can be reached as the firing temperature approaches $1500{ }^{\circ} \mathrm{C}$ [12]. The efficiency can be increased also by sequential combustion, i.e. additional fuel injection downstream of the highpressure stage of the GT [13-15]. In this application, the air is compressed to a higher pressure, but the firing temperature does not need to be increased to achieve enhanced performance and improved efficiency (Fig. 9) [14,15].

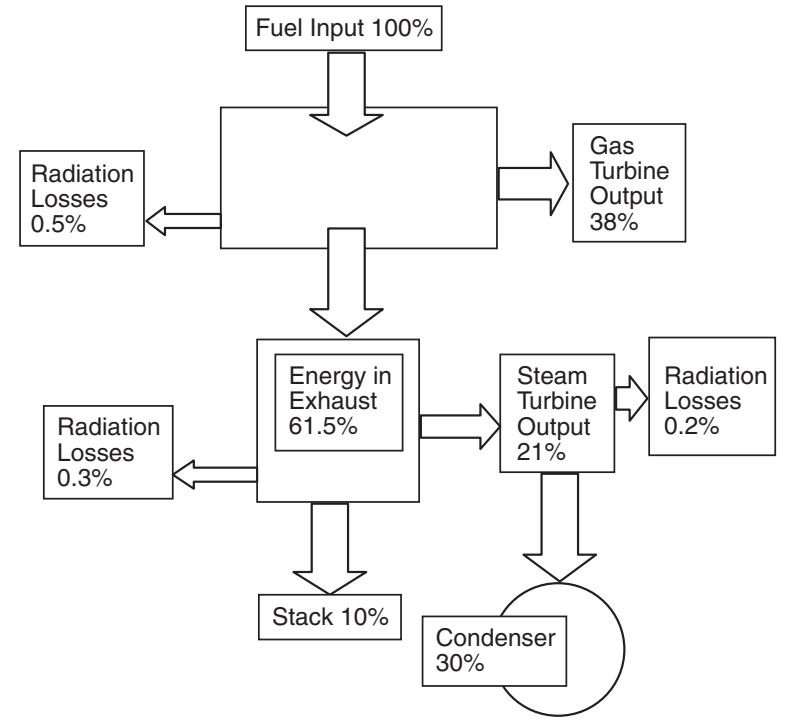

Fig. 8. Energy distribution in a combined cycle power plant.

Due to such high efficiencies and the low carbon to hydrogen ratio of NG, NGCC plants are environmentally favorable. As a result, they are capable of being sited close to areas of high population density, mainly as distributed generation, or as smaller, heat and power cogen plants. For application as central power generating plants, however, the high NG price is a disadvantage. This 


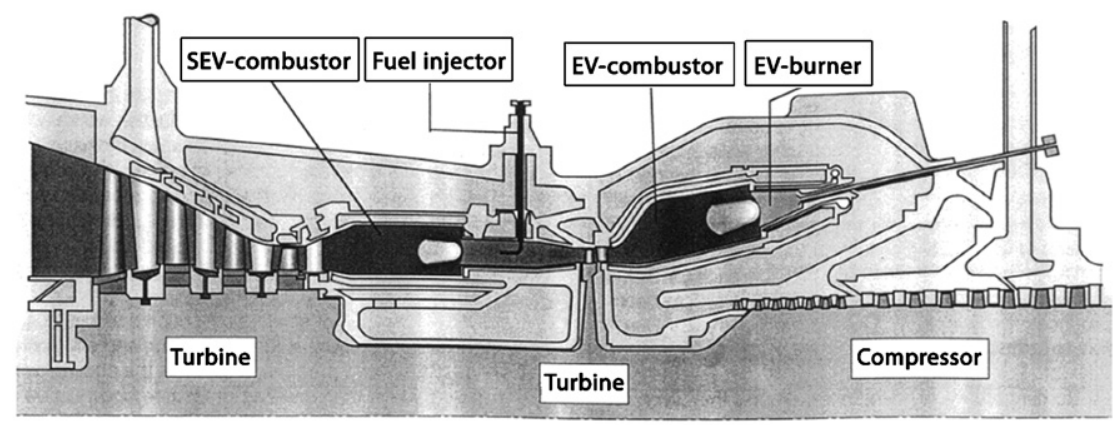

(a)

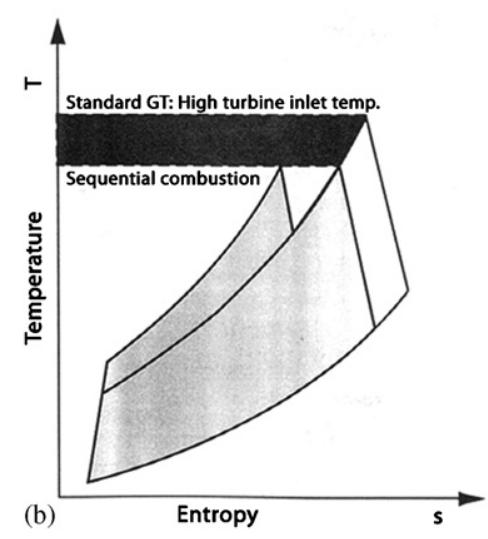

Fig. 9. (a) Gas turbine (GT26) hot gas path in the sequential combustion process [14,15]; (b) efficiency gain by sequential combustion without increase in GT firing temperature [15].

is turning the attention towards technologies capable of using coal in high efficiency GT-steam combined cycles for central power generation.

\subsection{Coal combustion combined cycles}

\subsubsection{Airheater GT combined cycles without NG topping combustion}

In these indirectly heated cycles compressed air is preheated in a coal fired boiler for use in a GT with optional addition of NG to raise the GT entry temperature, and the turbine exhaust is returned to the boiler as vitiated $\left(15 \% \mathrm{O}_{2}\right)$ air for combustion of the coal.

Atmospheric pressure circulating fluid bed boiler (CFB) raising steam and also preheating compressed air for an air turbine at 15 bar and $760{ }^{\circ} \mathrm{C}$ $\left(1400^{\circ} \mathrm{F}\right)$ [16]. The hot exhaust air leaving the turbine at $412{ }^{\circ} \mathrm{C}\left(773{ }^{\circ} \mathrm{F}\right)$ is used as combustion air to burn the coal in the CFB. The design of a $400 \mathrm{MW}$ power plant producing $85 \%$ of electricity by steam and $15 \%$ by air-turbine is demonstrated technology to meet environmental requirements. The net plant efficiency is calculated at $40.4 \%$ (LHV) (8872 Btu/kWh). The design has the advantages of simplicity, flexibility for coal quality variation, and the use of mature technologies. It avoids the problems arising from pressurized operation, coal gasification and gas cleanup for turbine operation. The CFB equipped with external heat exchangers allows corrosion-free oxidizing atmosphere for the operation of the air preheater constructed of special steel alloys [17]. The cycle efficiency can be further improved by raising the boiler steam parameters from their assumed values of 166 bar $538^{\circ} \mathrm{C} / 538^{\circ} \mathrm{C}\left(2407 \mathrm{psi}, 1000^{\circ} \mathrm{F}\right)$ to those of SC [16].

\subsubsection{Coal combustion in a $P C$ or $C F B$}

Coal combustion in a PC or CFB boiler generating steam, and preheating compressed air for a GT with the provision of raising the GT inlet temperature by the addition of NG in a topping combustor [18]. The example in Fig. 10 represents results of a design study [19]. Both coal and NG are used; $143 \mathrm{MW}$ is generated by the GT cycle, and $122 \mathrm{MW}$ by the steam cycle. The vitiated air $\left(\begin{array}{lll}15 \% & \mathrm{O}_{2}\end{array}\right)$ exhaust of the GT serves as the oxidant for burning the char in the boiler. The coal/NG ratio is $69 / 31 \%$, and the calculated combined cycle efficiency is $47.1 \%$ (LHV).

A material designated X5 NiCrCeNb3227 manufactured by Mannesmann AG [17] has been developed for pressurized air preheater tubes. Results of long-term testing were shown to be favorable for an air preheat of $760{ }^{\circ} \mathrm{C}$ to be maintained, and probably even exceeded. In the US DOE HIPPS program [20] materials development is planned to increase the air preheat further by $300{ }^{\circ} \mathrm{C}$ so as to reduce the $\mathrm{NG}$ energy contribution to the fuel mix from $31 \%$ to about $21 \%$.

\subsection{Coal gasification combined cycles}

Coal gasification is the key to coal use in combustion turbine (CT), and hence the means to increasing future coal-based power generation efficiency beyond $60 \%$. The fuel gas (syngas) composed mainly of $\mathrm{CO}$ and $\mathrm{H}_{2}$ can be produced by partial or total gasification of coal. Partial 


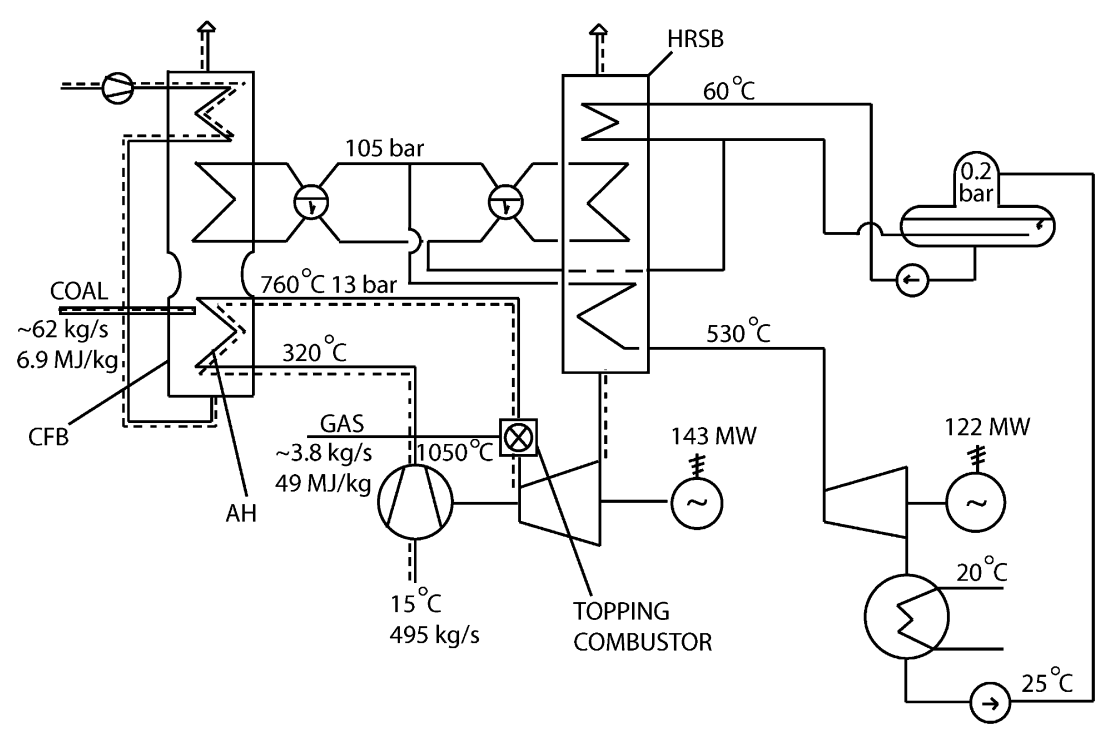

Fig. 10. High-performance power system (HIPPS) for Hungarian brown coal [19].

gasification [21,22] produces also a residual char for combustion, while in total gasification all the carbon in the feed coal is gasified.

\subsubsection{Partial gasification of coal}

Partial gasification of coal in a pressurized fluidized bed gasifier produce syngas for a topping combustor of the GT and char for combustion in a pressurized fluidized bed combustor (PFBC). The latter generates steam for the steam turbine and high-pressure flue gas for the GT in a GT-steam combined cycle (Fig. 11) [22]. The design has the usual advantages of fluidized beds: reduced sensitivity to fuel quality and sulfur capture by sorbents in the bed, and it responds also to the need of raising the GT inlet temperature by the use of NG. The combustion products of the char burning in the PFBC are cleaned of particulates and of alkali at $870{ }^{\circ} \mathrm{C}\left(1600^{\circ} \mathrm{F}\right)$, and are ducted to the GT where the syngas from the partial gasifier is injected. The PFBC exhaust gas has sufficient oxygen to burn the syngas in the topping combustor of the GT.

The topping combustor has to be of special design capable of being cooled by the $870{ }^{\circ} \mathrm{C}$ temperature PFBC exhaust gas, instead of the usual compressor exit air at $411^{\circ} \mathrm{C}$, without overheating. Also, it has to be a low $\mathrm{NO}_{x}$ combustor. Westinghouse's all metallic multi annular swirl burner (MASB) operating in Rich-Quench-Lean mode solves the cooling problem by creating thick layers of gas flow over the leading edges of overlapping concentric annular passages in the combustor, and gives $\mathrm{NO}_{x}$ emissions below $9 \mathrm{ppm}$ at $15 \% \mathrm{O}_{2}$ for syngas as fuel [23]. The plant is calculated to have $48.2 \%$ efficiency. If the syngas and the vitiated air effluent of char combustion are cooled to $538^{\circ} \mathrm{C}\left(1000^{\circ} \mathrm{F}\right)$, commercially available porous metal filters can be used instead of ceramic filters for particulate cleanup, and no alkali getters are needed. This reduces plant cost and increases availability, albeit at the expense of an efficiency reduction to $46 \%$ [23].

Comment: There are no vendors offering at present coal combustion CC plants (Section 3.2) or pressurized fluidized bed partial gasification plants (Section 3.3.1). The air-turbine cycles have been included for discussion because of their pioneering role in the idea of GT-steam cycles $[63,64]$, and the PFBC, because of the promise of high efficiency and fuel flexibility. The development of "warm", $800^{\circ} \mathrm{C}\left(1472^{\circ} \mathrm{F}\right)$, fuel gas and combustion product clean up that could capture vaporphase contaminants to prevent GT corrosion is a prerequisite for commercialization of PFBC partial gasification systems.

\subsubsection{Integrated gasification combined cycle (IGCC)}

Total gasification of coal changes the ratio between the GT and steam turbine power output from about $15 / 85$ for partial gasification to $55 / 45$. The combined cycle efficiency improves through the 


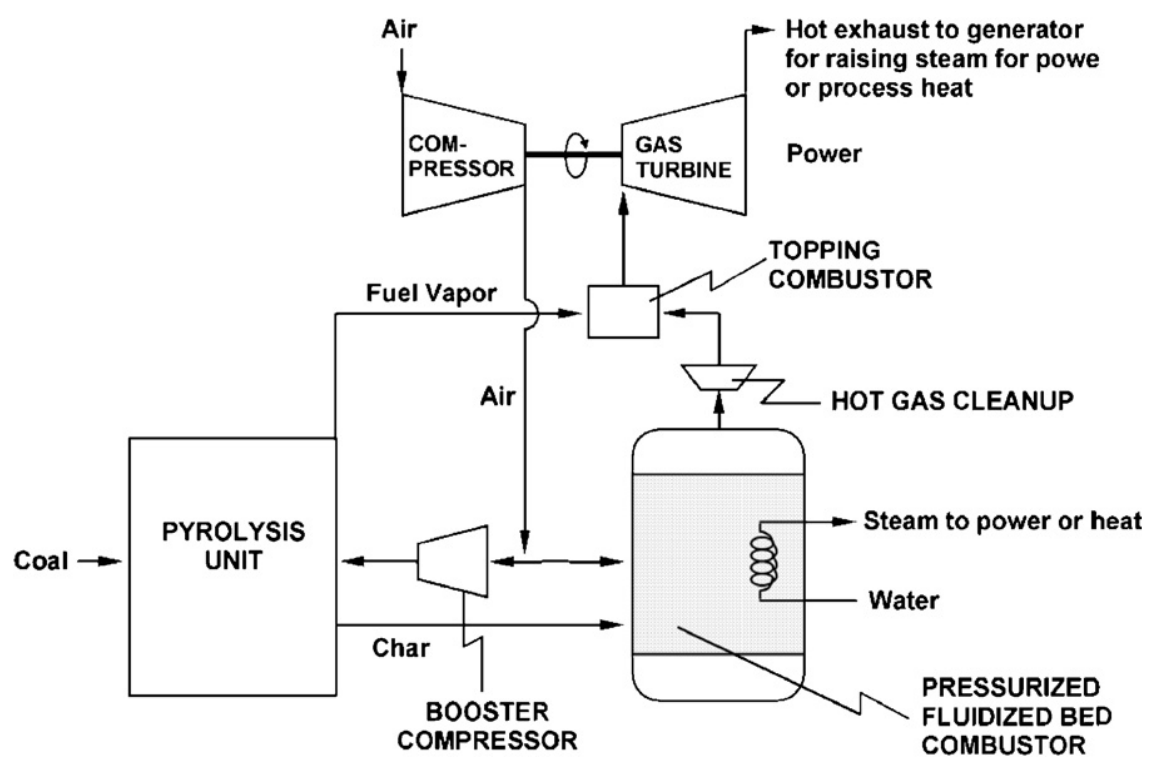

Fig. 11. PFBC with syngas topping combustor [22].

reduced effect of the steam condenser's heat loss. An IGCC block flow diagram is shown in Fig. 12.

Coal gasifiers applied to IGCC operation today include the Lurgi gasifier in Luenen, Germany, and four IGCC demonstration plants: the GE-Texaco gasifier in Tampa, Florida, the E-Gas gasifier inWabash, Indiana, the Shell gasifier in Bugganum in the Netherlands, and in Puertollano, Spain. A transport gasifier is under development at the USDOE Power systems Development Facility in Wilsonville Alabama. Coal gasifiers vary in their system of fix bed, fluidized bed or entrained flow; air or oxygen as oxidizer medium; dry coal or slurry feed, and dry or liquid ash (slag) removal.

Lurgi fixed bed gasifiers have a long history and are widely applied for syngas production [24,25]. In their original form brown coal was gasified with oxygen-steam mixtures and the ash was removed in dry form by a rotating grate that also supported the bed. Extensive commercial experience was gained with pressurized dry ash Lurgi gasifiers at Sassol synfuel plants in South Africa. Further development occurred via Lurgi's cooperation with British Gas that resulted in the BGL Slagging Gasifier.

BGL gasifiers are vertical reactors (Fig. 13). The coal is fed from the top through a lock hopper and. gasified in a fixed bed by a mixture of oxygen and steam introduced near the bottom of the bed through nozzles (tuyers). The predominant reaction at the bottom of the bed is combustion of the devolatilized char. The high temperature causes the

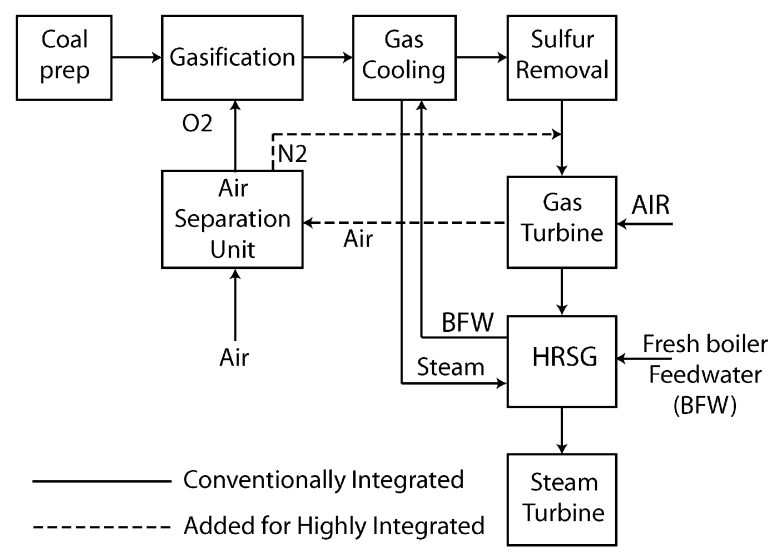

Fig. 12. IGCC block flow diagram (2005. Electric Power Research Institute Inc., J.N. Phillips [26]. Reprinted with Permission).

ash to melt, and the fluid slag is removed via a slag lock hopper. The gaseous combustion products $\mathrm{CO}_{2}$ and $\mathrm{H}_{2} \mathrm{O}$ rise in the bed and are getting reduced by their reactions with carbon to form carbon monoxide, hydrogen and methane. On further rise in the bed the gas is enriched with coal volatiles and moisture. These processes yield hydrocarbons, mainly tars, oils and methane, sulfur compounds and steam, which are carried out by the product gas. Because of the counter current flow of coal and gas, the gas leaves at low temperature and there is no need for refractory protection of the reactor wall; the reactor's water jacket gives sufficient protection even in the high-temperature ash-melting zone. 


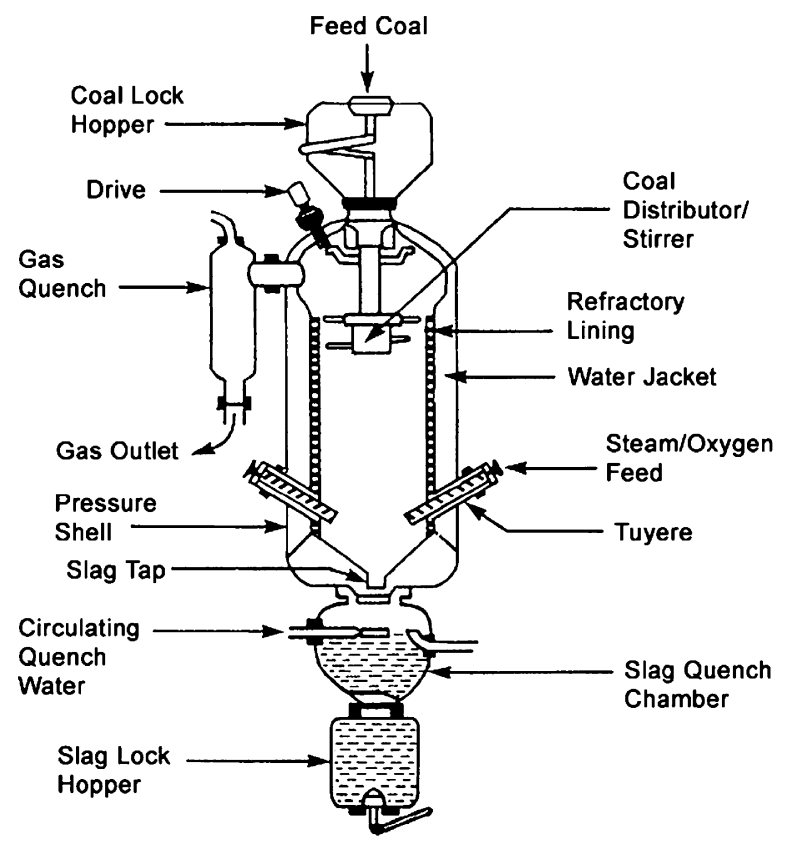

Fig. 13. The BGL slagging gasifier [24].

In more recent applications of gasifiers for IGCC plants, entrained flow gasification is seen as the preferred system. This is mainly due to the greater flexibility of entrained flow gasification for using coal fines or caking coals in the feed, and easier scale up of the gasifier to match the performance of up to date GTs.

High-temperature entrained flow gasification (Figs. 14 and 15) has the advantage of avoiding tar formation and its related problems, and of yielding increased rates of gasification that makes it easier to match the capacity of a single gasifier to that of a modern GT. High-pressure gasification reduces the cost of syngas clean-up because of the smaller size of equipment, and saves auxiliary power for the compression of syngas, and of $\mathrm{CO}_{2}$, when, at a later date $\mathrm{CO}_{2}$ capture for sequestration is considered.

High-pressure and high-temperature operation, however, has implications for the modes of coal feeding and ash removal, and as a consequence, may affect the coal property range that can be handled by a gasifier. Coal can be fed into a high-pressure entrained flow gasifier either as dry coal by lock hoppering or as coal-water slurry, pumped and sprayed through injectors. The technology of feeding coal water slurries (CWS) has broad coverage in the literature due to the 1980s interest in coal water slurry combustion $[27,28]$.
While air-blown gasifiers save the capital cost and energy consumption of an oxygen plant, the lower calorific value of the syngas they produce makes hot gas particle cleanup, a technology still under development, indispensable. Also, the larger volume of gas to be treated increases the size and cost of all gas cleaning equipment.

Dry coal-feed gasifiers (e.g., Shell, Fig. 16) are more appropriate for low rank, high moisture coals. High moisture coals, however, have to be predried in preparation for lock hoppering and pneumatic conveying. This leads to energy penalty because of reduced steam turbine output due to the present practice of steam drying. A dry feed pump system (Stamet pump) is under development in the US DOE IGCC RD\&D Program [30]. It promises reduced cost, coal feed without lock hoppers and improvement of plant efficiency by about 0.5 percentage points.

Slurry feeding (GE-Texaco, Conoco-Phillips) does not require lock hoppers because the CWS is an incompressible fluid that can be pumped to the burners of a pressurized gasifier. There is about $35 \%$ water in the slurry of a high-quality bituminous coal. The water content of the slurry varies with coal type and more strongly with particle size fineness; as the coal is ground more finely, more water is needed to maintain sufficiently low viscosity for trouble free slurry transportation. Slurry viscosity can be reduced also by additives that make the coal more hydrophilic [27]. Because of its high initial water content, slurry feed does not lend itself well for gasification of high-moisture coals.

\subsubsection{Dry or liquid ash (slag) removal. Physical} and chemical transformations of coal ash upon heating are discussed by Reid [31]. Most coal ash samples show initial deformation and become sticky at around $1100{ }^{\circ} \mathrm{C}$ and melt at $1300-1400{ }^{\circ} \mathrm{C}$. These temperatures depend on the chemical composition of the ash and are somewhat higher for oxidizing, than for reducing conditions. The fouling of convective heat exchange surfaces, e.g., Syngas cooler, by semi-molten ash deposited is a major cause of forced plant outage. By increasing the operating temperature of the gasifier to beyond the melting point of the ash, up to $90 \%$ of the coal ash can be removed in liquid form (slag), significantly reducing thereby the mass flow rate of ash liable to forming deposits in convective heat exchangers.

Conditions for reaching the elevated temperatures required for liquid ash removal include coal of 


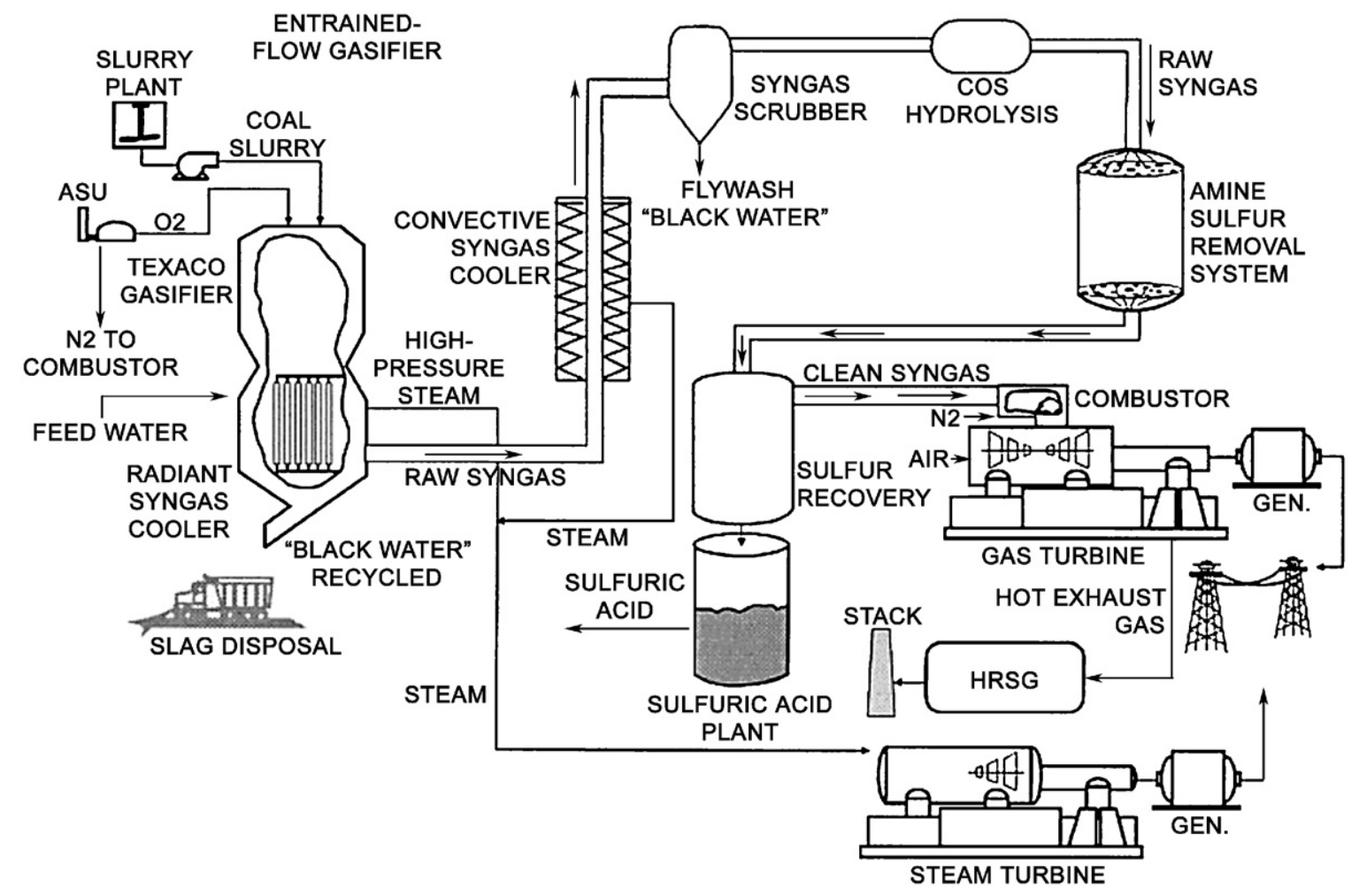

Fig. 14. IGCC with GE-Texaco entrained-flow, top-feed, gasifier (Courtesy NETL).

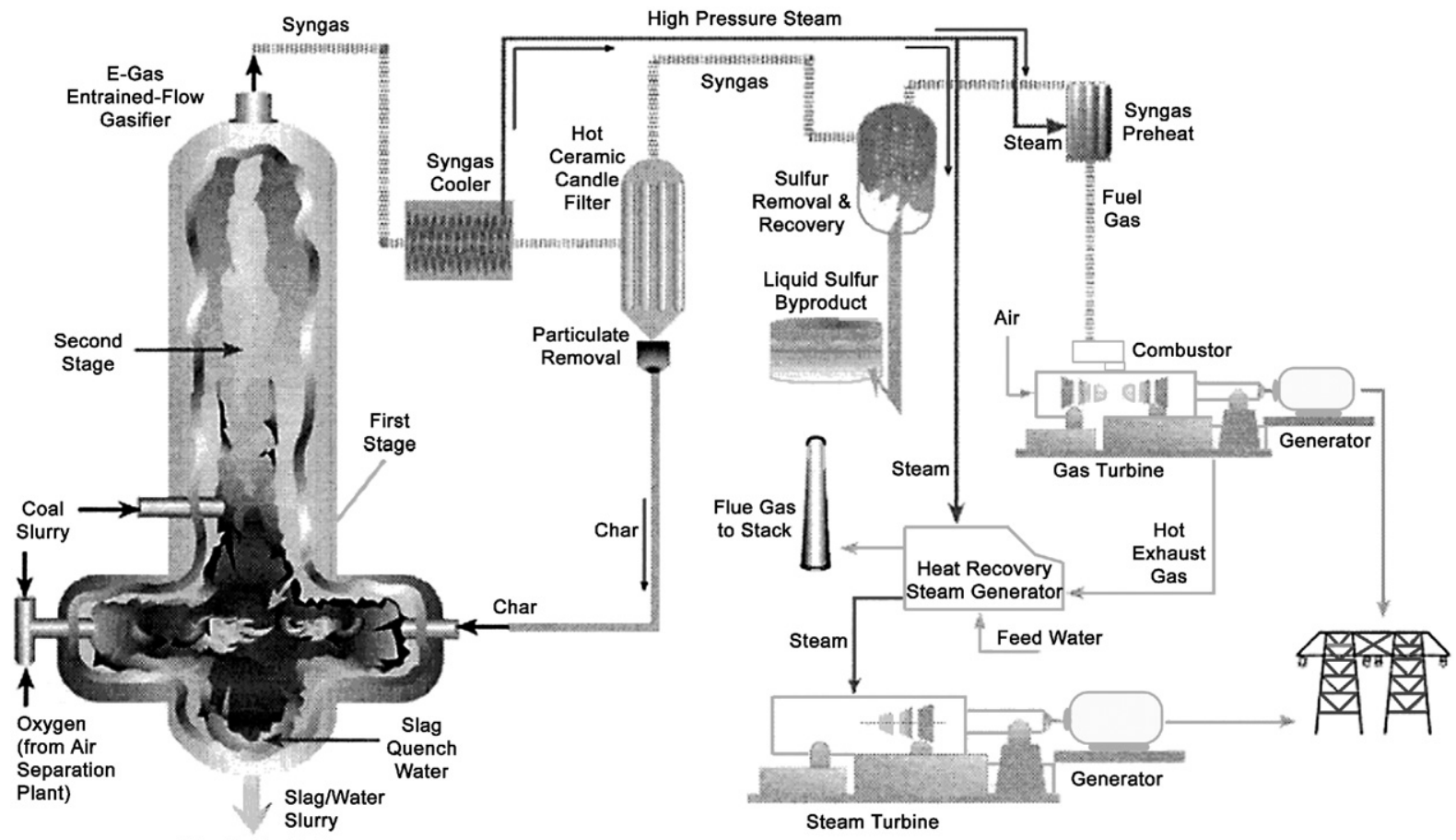

Slag By-Product

Fig. 15. IGCC with E-gas entrained flow, two stage feed gasifier (Courtesy NETL). 


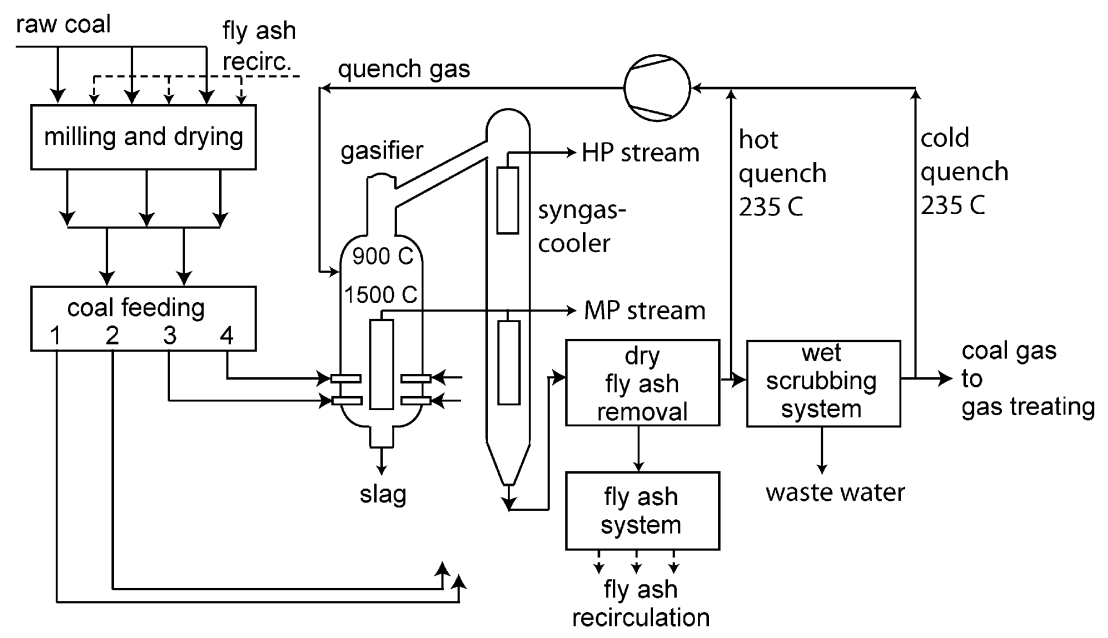

Fig. 16. Shell dry feed gasifier [29].

high heating value, coal ash with favorable melting-viscosity characteristics, and sufficiently high oxygen concentration of the feed stream. For low rank and/or high ash (low heating value) coals more oxygen has to be used to reach the temperature required for reducing the slag viscosity to the 250-300 poise range, required for trouble-free slag removal. The technology of liquid slag removal and slag heat recovery is discussed in detail by Dolezal [32,33].

Gasifier design has effect on the ease of slag removal and on high-pressure operation. In the Texaco gasifier with top coal-oxygen feed (Fig. 14), the maximum flame temperature is in the region close to the top, while the slag tap is at the bottom of the gasifier, where the gas temperature is lower due to heat extraction along the path down the gasifier. As the temperature is raised on the top to ensure that the molten slag flows through the taphole, care has to be taken not to damage the refractory lining of the gasifier. In the two-stage design of the E-Gas gasifier (Fig. 14), the first stage coal-oxygen feed-stream creates a sufficiently hightemperature zone right above the slag tap enabling fluid slag removal for a wider range of coal types and ash qualities.

\subsubsection{Gasifier wall refractory lining or cooling.} Gasifiers are either refractory lined or have membrane walls cooled by steam. The slurry fed gasifiers (Texaco, E-Gas) are refractory lined which is one of the factors that limits their availability and require a spare gasifier for higher than $80 \%$ capacity factor operation. Research is in progress sponsored by the US DOE [39] to develop more durable refractories by phosphate addition to the chromium oxide-based refractory presently used in slagging gasification. This should lengthen the planned refractory replacement time from the present 6-18 months to 36 months increasing the plant availability by $4-6 \%$ points.

The dry coal-feed Shell gasifier has membrane walls and is capable of higher capacity factor operation without sparing, but is a more expensive plant. In membrane panels tube rows centered on space wider than a tube diameter are joined by a membrane bar (or fin) welded to the adjacent tubes. This results in a continuous, cooled metallic wall surface. During operation the membrane wall is covered by slag that protects the tubes from excessive thermal load. Theoretically, the fireside temperature and viscosity of the slag layer remains the same over the variation of the thermal load. The thickness of the slag layer increases at low load reducing thereby the tube's cooling effect, and it becomes thinner at high load that makes for more effective cooling. In this way an operating range can be found both for trouble free slag removal and protection of the membrane wall from excessive thermal load [32].

Slender design of the Texaco gasifier makes it capable of operating at higher pressures (69 bar) than the E-Gas gasifier (35 bar) which, in turn, saves auxiliary energy, and raises the net plant efficiency especially for the case of $\mathrm{CO}_{2}$ capture and compression in preparation for sequestration. 


\subsubsection{Transport gasifier IGCC (in the US DOE} $R \& D$ portfolio $[65])$. The transport reactor (Fig. 17) is an outgrowth of the CFB development. Gas velocities which are in the range of $6-12 \mathrm{~m} / \mathrm{s}$ $(18-66 \mathrm{ft} / \mathrm{s})$ in CFB are increased to $12-18 \mathrm{~m} / \mathrm{s}$ in the transport reactor. At these higher velocities particles of $0.5-5.0 \mathrm{~mm}$ sizes are all carried with the gas and full pneumatic transport is achieved. Vigorous solids recirculation produces intense gas-solid mixing, higher riser solids densities and increased residence times that all improve conditions for gas-solids reactions.

In gasification applications the coal and the limestone are fed through separete lock hoppers to the transport gasifier operating at up to $18 \mathrm{bar}$ (260 psi) pressure. Oxygen and steam, introduced at the bottom mix with the solids in the mixing zone, a larger diameter lower section of the vertical reactor and raise the temperature to about $1060^{\circ} \mathrm{C}$ $\left(1940^{\circ} \mathrm{F}\right)$ by burning the recirculated char. The coal and sorbent are fed into the flow of the hot combustion products at the top of the mixing zone and carried into the riser where the coal is devolatilized and gasified and the sulfur is captured as calcium sulfide. From the riser the larger particles are separated from the gas by gravity, and the smaller ones by centrifugal force in the cyclone. The solids are then recycled to the mixing zone through a standpipe and the non-mechanical "J-valve." Fine particles that escape the cyclone are cooled in a heat exchanger to below $800^{\circ} \mathrm{F}\left(427^{\circ} \mathrm{C}\right)$ and removed from the gas by banks of metal filter elements in a

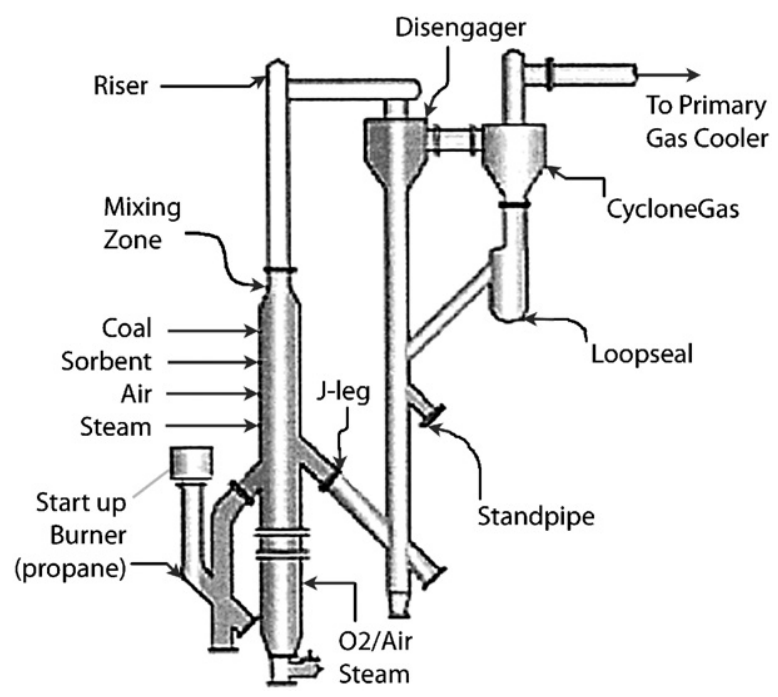

Fig. 17. The transport reactor system. vessel, called particulate control device (PCD) developed by Siemens Westinghouse.

Southern Company is developing the transport gasifier for application in the power industry, a 285 MWe IGCC plant is planned in Orlando based on air blown gasification with the support of the US Department of Energy (DOE) and Kellog, Brown and Root Inc. (KBR).

Since $1999,6500 \mathrm{~h}$ of operation have been completed with a pilot scale transport gasifier at the DOE Power System Development Facility (PSDF) in Wilsonville, AL [65]. Several coals, including Illinois bituminous, high sodium Freedom mine lignite, and Powder River Basin subbituminous coal, have been gasified in both air-blown and oxygen-blown operations.

The transport gasifier promises several advantages over commercially available gasifiers. These include fuel flexibility (easy gasification of low grade and high ash melting coals), and simple mechanical design. Because it is capable of air-blown operation, the efficiency of a transport gasifier-based IGCC is promised to be about one percentage point higher, the capital cost by about $\$ 50 / \mathrm{kW}$ lower, and the availability about $2 \%$ higher than those of present day commercially available IGCC plants.

3.3.2.4. Subsystems integration. In the IGCC process there is potential for high degree of subsystems integration. Steam generated in the gasifier is superheated in the syngas cooler, compressed air is supplied by the main compressor of the CT for the air separation unit, from where nitrogen is returned to the GT as a diluent to reduce the $\mathrm{NO}_{x}$ formation in the combustor, and to enhance the performance by increased mass flow rate through the turbine (see Fig. 12).

Operators of the Tampa Texaco IGCC report efficiency of $38.5 \%$ (LHV), the Wabash E-Gas plant $42.7 \%$ (LHV), while the more highly integrated Shell IGCCs at Buggenum in the Netherland and at Puortellano in Spain have efficiencies of $43 \%$ and $45 \%$ (LHV), respectively. There is, however, a balance between the advantage of efficiency gain due to increased subsystems integration and the disadvantage of a more complicated plant with reduced availability. As a result, IGCC plants offered commercially in the near term are likely to have lower degree of subsystems integration, higher availability but somewhat reduced plant efficiency.

Fig. 18 is an illustration of the energy distribution in a gasification combined cycle. After gasification 


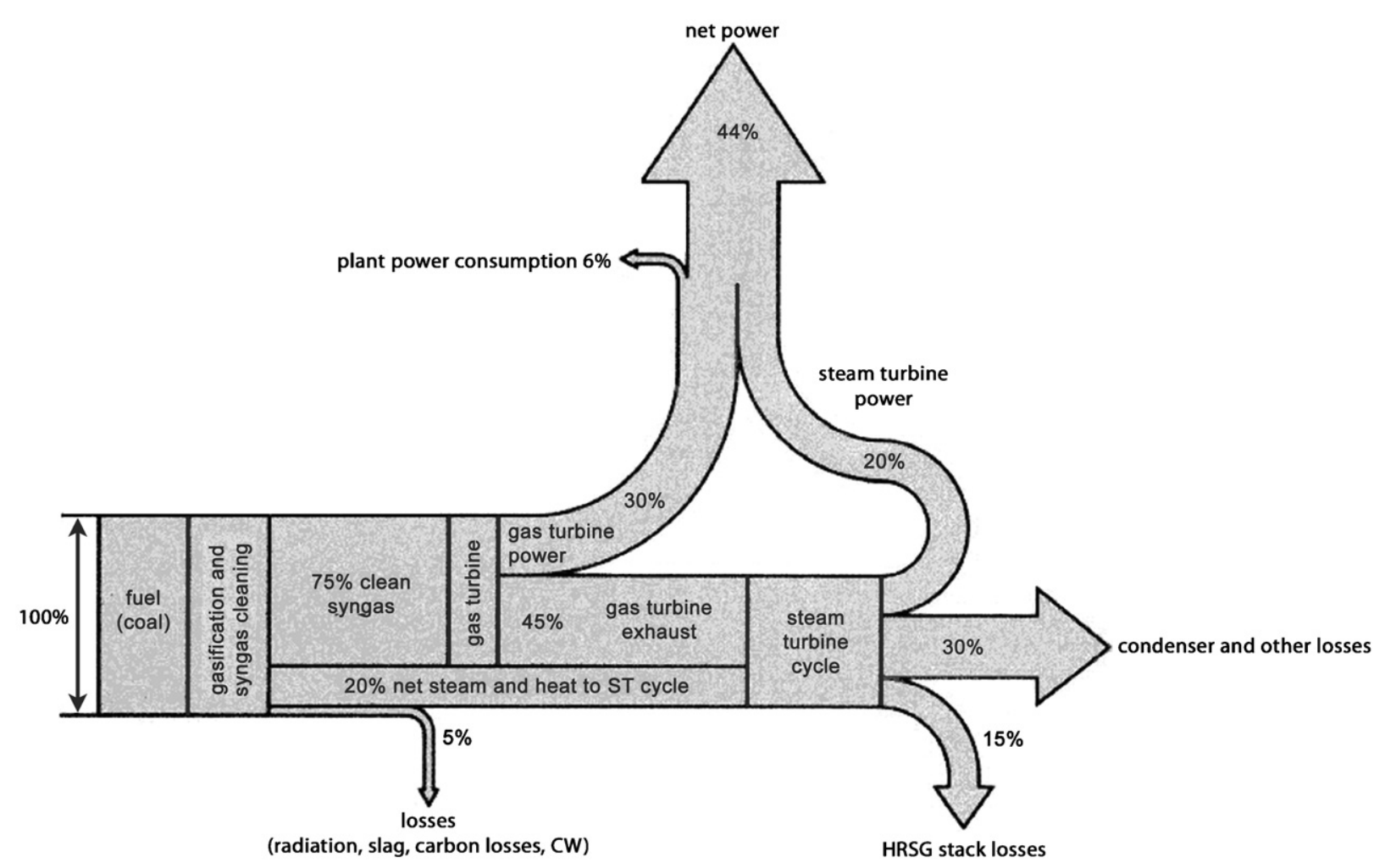

Fig. 18. Energy flow diagram for IGCC [34].

and gas clean-up $75 \%$ of the energy input is left in the syngas; of this, $30 \%$ generates power in the GT and $20 \%$ in the steam turbine. Because of the higher efficiency of the GT cycle, gasification processes that produce syngas with higher chemical energy and less sensible heat for steam rising improve the combined cycle efficiency.

There are, however trade-offs as noted by Holt [43]: the calorific value of the syngas increases with more methane production at higher gasifier pressure, with the concomitant improvement of the combined cycle efficiency, but this reduces the mass fraction of the combustible gas, $\mathrm{CO}$, that can be converted to $\mathrm{CO}_{2}$ with water by the shift reaction.

\subsubsection{GT inlet temperature. The IGCC efficiency} depends strongly upon the performance of the GT and, in turn, on the GT inlet temperature. The effect of GT inlet temperature upon the efficiency of combined cycles is presented in Fig. 19 [35,36]. Present day NG-fired GTs can operate at $1550 \mathrm{~K}$ inlet temperature but the high hydrogen content of syngas and its saturation by steam and the injection of nitrogen from the ASU to reduce $\mathrm{NO}_{x}$ formation results in increased mass flow of combustion products that transfer more heat to the structural parts of the turbine. This requires, presently, the lowering of GT firing temperature, with the consequence of reducing the cycle efficiency by about 3 percentage points [37]. R\&D in progress [38] on closed cycle steam cooling of turbine blades, improved thermal barrier coatings, and combustor development for a hydrogen-fueled low $\mathrm{NO}_{x}$ emission GT hold the key to increasing further the cycle efficiency.

3.3.2.6. Air separation for oxygen supply. Cryogenic air separation that supplies $95 \%$ or greater purity oxygen for IGCC operation is mature technology, but it consumes about $10 \%$ of the gross power output and requires about $15 \%$ of the total plant cost. R\&D is in progress sponsored by US DOE [39] at Air Products and Chemicals on the development of ion transfer membrane (ITM) air separation technology, in which oxygen is transported at $540{ }^{\circ} \mathrm{C}$ temperature through a ceramic membrane. The air supply to the ITM is a bleed stream from the GT compressor and the product $\mathrm{O}_{2}$ 


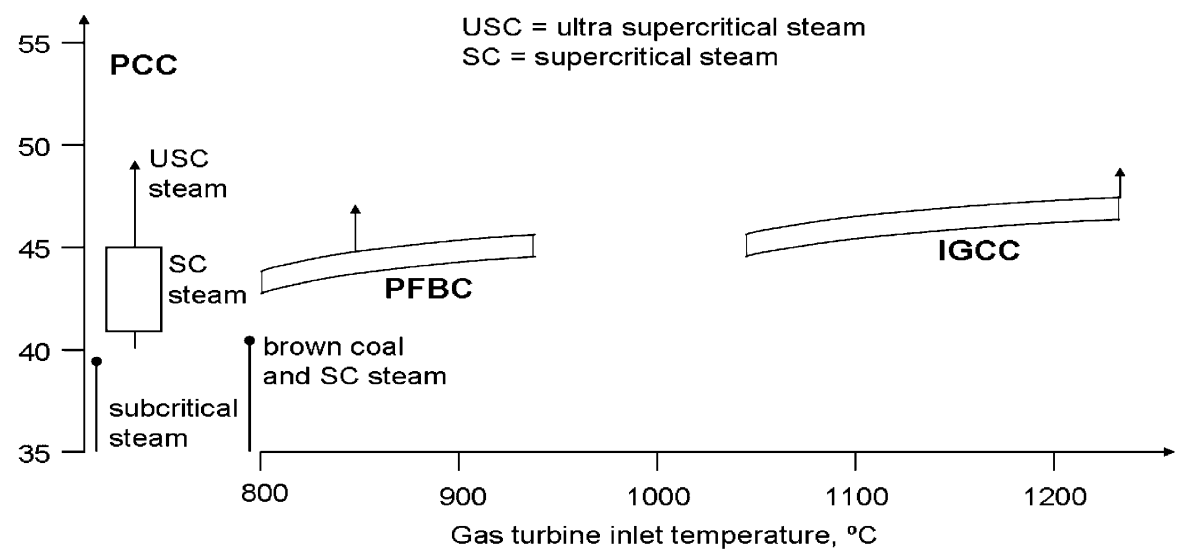

Fig. 19. Effect of gas turbine inlet temperature on the efficiency of high-efficiency power generating cycles [35,36].

has to be further compressed for its feed to the gasifier. Successful development of ITM promises improvement of IGCC efficiency by one percentage point, and reduction of the capital cost by $\$ 75 / \mathrm{kW}$ $(\sim 5 \%)$ [39].

\subsubsection{Environmental performance of IGCC} plants. The environmental performance of coalbased power plant systems of different efficiency (HHV) presented and compared with those of a NG-fired combined cycle plant [1] is presented in Fig. 20. Comparison of emissions from PC plants with a fleet average efficiency of $32 \%$ illustrate the potential environmental improvement that can be attained by the deployment of advanced, higher efficiency coal-based power plants, e.g., PC/USC, PCFB, or IGCC. Also, IGCC is seen as today's environmentally cleanest advanced coal plant system.

3.3.2.8. Costs and efficiency. IGCC plants are presently not cost competitive with other advanced coal-burning systems such as PC-fired SC Plants. Nevertheless, there are considerations which may, in the future tilt the balance in favor of IGCC applications: IGCC lends itself for the efficient removal of $\mathrm{CO}_{2}$ from the high-pressure fuel gas, and mercury emissions can be controlled at significantly lower cost than in PC combustion.

Results of an EPRI study [29] on comparative average data of capital and operating expenses and on efficiency of subcritical steam and advanced power generation technologies, without $C C S$, are shown in Table 3.

Assumptions used to derive results in Table 3: book life: 20 years; commercial operation date: 2010; total plant cost (TPC) includes engineering and contingencies; total capital requirement (TCR) includes interest during construction and owners' cost; assumes EPRI's TAG financial parameters; Comment: All costs in 2004 dollars and do not include the impact of recent construction cost increases. It is appreciated that costs may vary depending upon location and time. Relative costs of different energy conversion systems, however are less prone to such variation. Also, the IGCC performance is based on "FA" gas turbine technology (197MW) while the major gasification vendors are now developing their standard offerings based on "FB" technology (232MW) with improved efficiency and better economies of scale.

For average heat rate and COE there is little difference between PC/SC and IGCC plants. The total capital requirement (TCR) for the IGCC is $8 \%$ higher, and the cost of electricity (COE) 7\% higher than for the PC/SC. Heat rate and capital cost are increasing with decreasing coal quality, more steeply for IGCC than for PC as shown in Fig. 21 [37]. For the Shell gasification process in which lower level process heat is used to dry high moisture-content lignites and subbituminous coals before feeding to the gasifier, the rates of increase in capital cost and heat rate with decreasing fuel quality are about the same as for PC plants [68].

As the coal's calorific value decreases more coal and more oxygen need to be used, and increased auxiliary energy expended for the handling of the larger amount of coal. Also, gasification of lower rank coal shifts the energy content of the productgas towards more sensible heat for the less efficient steam cycle and less chemical energy for the more efficient GT cycle, resulting in reduced combined cycle efficiency. 


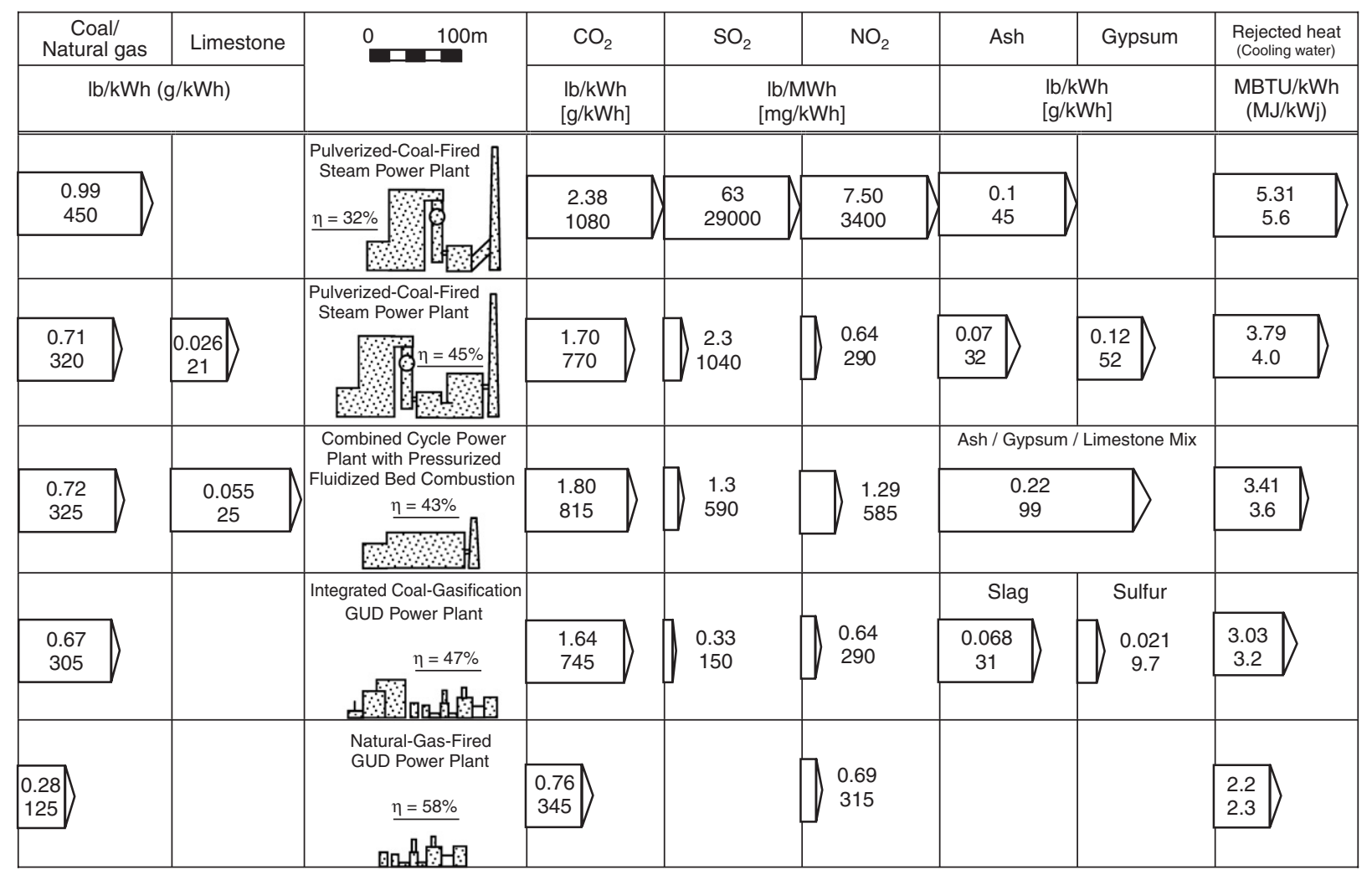

Fig. 20. Comparison of emissions and by-products for different $600 \mathrm{MW}$ plants ([40], modified by Thermuehlen and Empsperger [1]).

Table 3

Costs and efficiency for $500 \mathrm{MW}$ power plants using a range of technologies without CCS (2004. Electric Power Research Institute Inc., N. Holt [29]. Reprinted with Permission).

\begin{tabular}{|c|c|c|c|c|c|c|c|}
\hline & $\begin{array}{l}\text { PC sub- } \\
\text { critical }\end{array}$ & $\begin{array}{l}\text { PC super- } \\
\text { critical }\end{array}$ & CFB & $\begin{array}{l}\text { IGCC (E-gas) } \\
\text { W/spare }\end{array}$ & $\begin{array}{l}\text { IGCC (E-gas) } \\
\text { No spare }\end{array}$ & $\begin{array}{l}\text { NGCC } \\
\text { high CF }\end{array}$ & $\begin{array}{l}\text { NGCC } \\
\text { low CF }\end{array}$ \\
\hline Total plant cost, $\$ / \mathrm{kW}$ & 1230 & 1290 & 1290 & 1350 & 1250 & 440 & 440 \\
\hline $\begin{array}{l}\text { Total capital requirement, } \$ / \mathrm{kW} \\
\text { Avg. heat rate }\end{array}$ & 1430 & 1490 & 1490 & 1610 & 1490 & 475 & 475 \\
\hline $\mathrm{Btu} / \mathrm{kWh}(\mathrm{HHV})$ & 9310 & 8690 & 9800 & 8630 & 8630 & 7200 & 7200 \\
\hline$\eta \%(\mathrm{HHV})$ & 36.7 & 39.2 & 34.8 & 39.5 & 39.5 & 47.4 & 6840 \\
\hline$\eta \%(\mathrm{LHV})$ & 38.6 & 41.3 & 36.7 & 41.6 & 41.6 & 50.0 & $47.4 / 50$ \\
\hline $\begin{array}{l}\text { Levelized fuel cost, \$/MBtu } \\
(2003 \$)\end{array}$ & 1.50 & 1.50 & 1.00 & 1.50 & 1.50 & 5.00 & 5.00 \\
\hline Capital, \$/MWh (levelized) & 25.0 & 26.1 & 26.1 & 28.1 & 26.0 & 8.4 & 16.9 \\
\hline O\&M, \$/MWh (levelized) & 7.5 & 7.5 & 10.1 & 8.9 & 8.3 & 2.9 & 3.6 \\
\hline Fuel, \$/MWh (levelized) & 14.0 & 13.0 & 9.8 & 12.9 & 12.9 & 36.0 & 36.0 \\
\hline COE, \$/MWh (levelized) & 46.5 & 46.6 & 46.0 & 49.9 & 47.2 & 47.3 & 56.5 \\
\hline
\end{tabular}

3.3.2.9. Availability. There is a perception in the utility industry of reduced IGCC availability [41]. Fig. 22 shows the history of availabilities for IGCC demonstration plants [67]. The graph illustrates the learning curve nature of these histories reaching about $80 \%$ availability.
The main cause of planned and forced outages is the gasification block This is due to the relatively short life of slurry feed injector nozzles (2-3 months), refractory lining 6-18 months), corrosion and fouling of syngas coolers, and the single train operational nature of oxygen-blown pressurized 


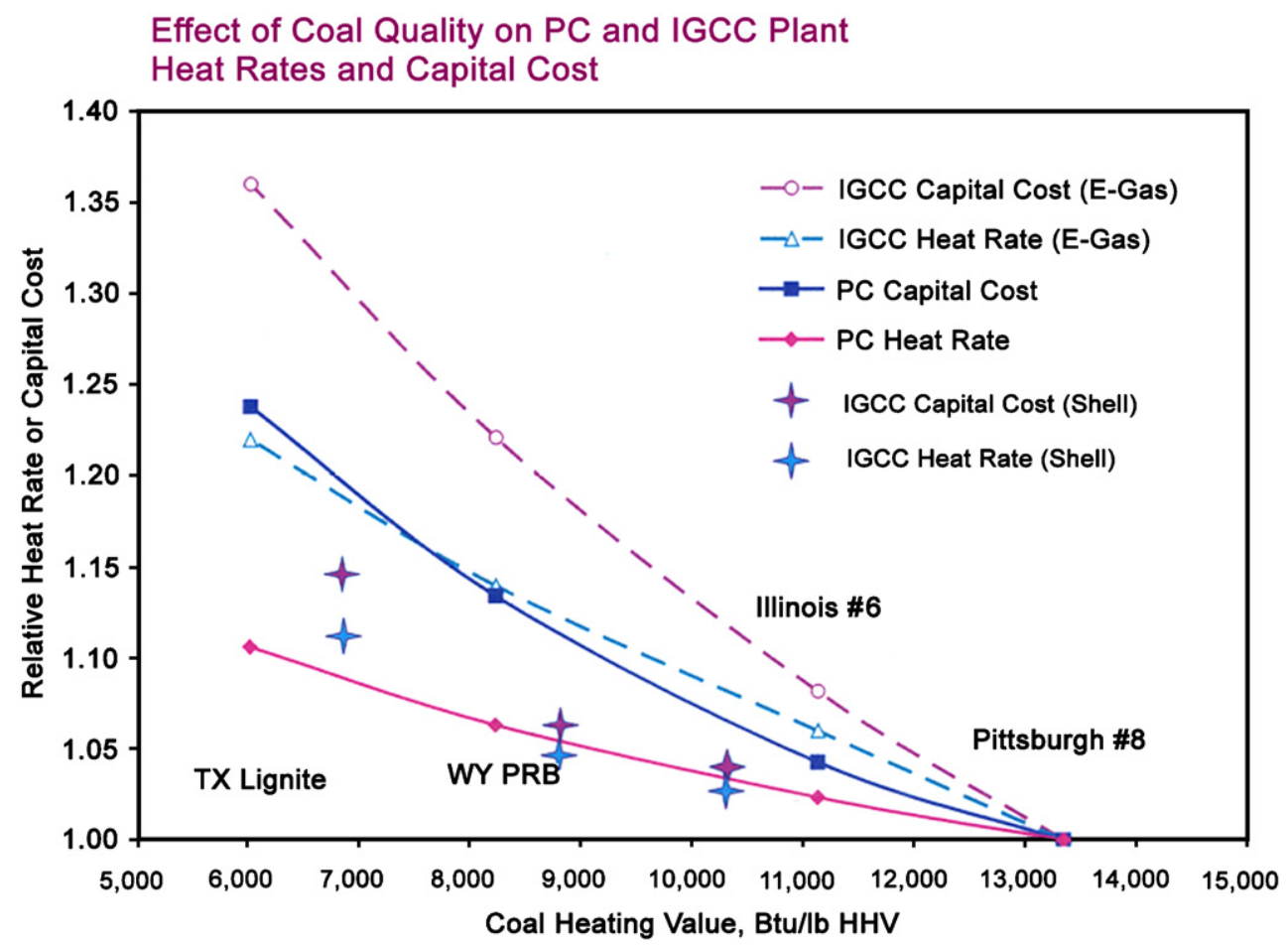

Fig. 21. Effect of coal quality upon heat rate and capital cost of PC and IGCC (2004. Electric Power Research Institute Inc., Holt, Booras and Todd, EPRI [37], with recent addition of data for IGCC Shell with coal pre-drying N. Holt [68]. Reprinted with Permission).

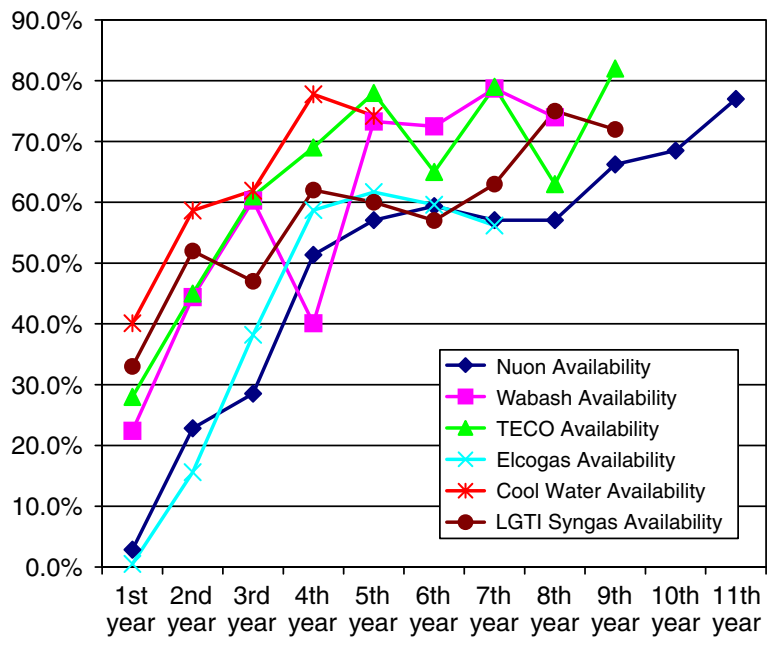

Fig. 22. History of IGCC availability (excluding operation on back-up fuel) (2005. Electric Power Research Institute Inc., J. Phillips [67]. Reprinted with Permission).

gasification, i.e., when a component in the system goes down, it cannot be bypassed, it stops the whole plant.
IGCC projects in the US DOE R\&D portfolio [39] include the development of more durable refractory for lining the gasifier walls. The chromium oxide-based refractory used in these hightemperature gasifiers is attacked by the molten slag. New refractory formulations based on phosphate additions are being tested at the Wabash and Polk IGCC plants, and the initial results are promising. Other areas of research are aiming at improved instrumentation for the direct measurement of peak temperatures in the gasifier, in-situ measurement of slag viscosity, on-line measurement of refractory wear, and measurement of feed coal properties. Also, more commercial IGCC plants would need to be constructed and operated soon to overcome the negative perception of IGCC availability.

When $\mathrm{CO}_{2}$ sequestration becomes commercial, IGCC with $\mathrm{CO}_{2}$ capture and sequestration (CCS) will be expected to have cost advantage over $\mathrm{PC} / \mathrm{SC}$ with CCS due partly to the lower cost of $\mathrm{CO}_{2}$ removal, and also, because in IGCC the $\mathrm{CO}_{2}$ will be available at high pressure, and little or no additional capital expenditure and energy will be required for its compression and liquefaction in preparation for sequestration. 


\subsection{Hybrid gasification-fuel cell-GT-steam combined cycles}

\subsubsection{The DOE's Vision21 cycle [40] (in the DOE $R \& D$ portfolio)}

One of the promising coal-fired advanced cycles expected to be ready for demonstration in the 2010-2015 period is the US DOE's Vision21 cycle (Fig. 23). The fuel gas produced in an oxygen-blown gasifier at elevated pressure is cleaned at a temperature of $1273 \mathrm{~K}$. The gas composed mainly of $\mathrm{H}_{2}$ and $\mathrm{CO}$ enters a solid oxide fuel cell (SOFC) on the anode side, while air from a compressor exhaust preheated in a recuperator enters on the side of the cathode. The hydrogen is used to generate electricity in the SOFC, and the CO burns in a CT that drives the compressor. Electric power is produced in another SOFC and a GT, at a lower pressure, downstream of the high-pressure turbine with more power added by a bottoming steam cycle. The efficiency could reach $60 \%$ in this near zero emission scheme. The DOE-Industry-University R\&D program is aiming at the development of individual modules of this cycle and the complex control system required for flexible load following. One of the R\&D challenges is the clean up of the fuel gas of vapor-phase contaminants before entry to the SOFC and the GT. Demonstration is expected within the FutureGen program during the 2012-2020 period.

\section{4. $\mathrm{CO}_{2}$ capture and sequestration (CCS) capable technologies}

\subsection{Oxygen-blown pressurized gasification of coal ( IGCC)}

IGCC lends itself favorably for efficient $\mathrm{CO}_{2}$ capture and sequestration because $\mathrm{CO}_{2}$ can be separated from a relatively small volume of fuel gas (syngas) at high pressure. This is in contrast to conditions of coal combustion with air as oxidant, where the flue gas volume is much larger, and $\mathrm{CO}_{2}$ concentrations in the atmospheric pressure combustion products are low, typically $12-14 \%$. The larger gas volume to be cleaned results in increased size
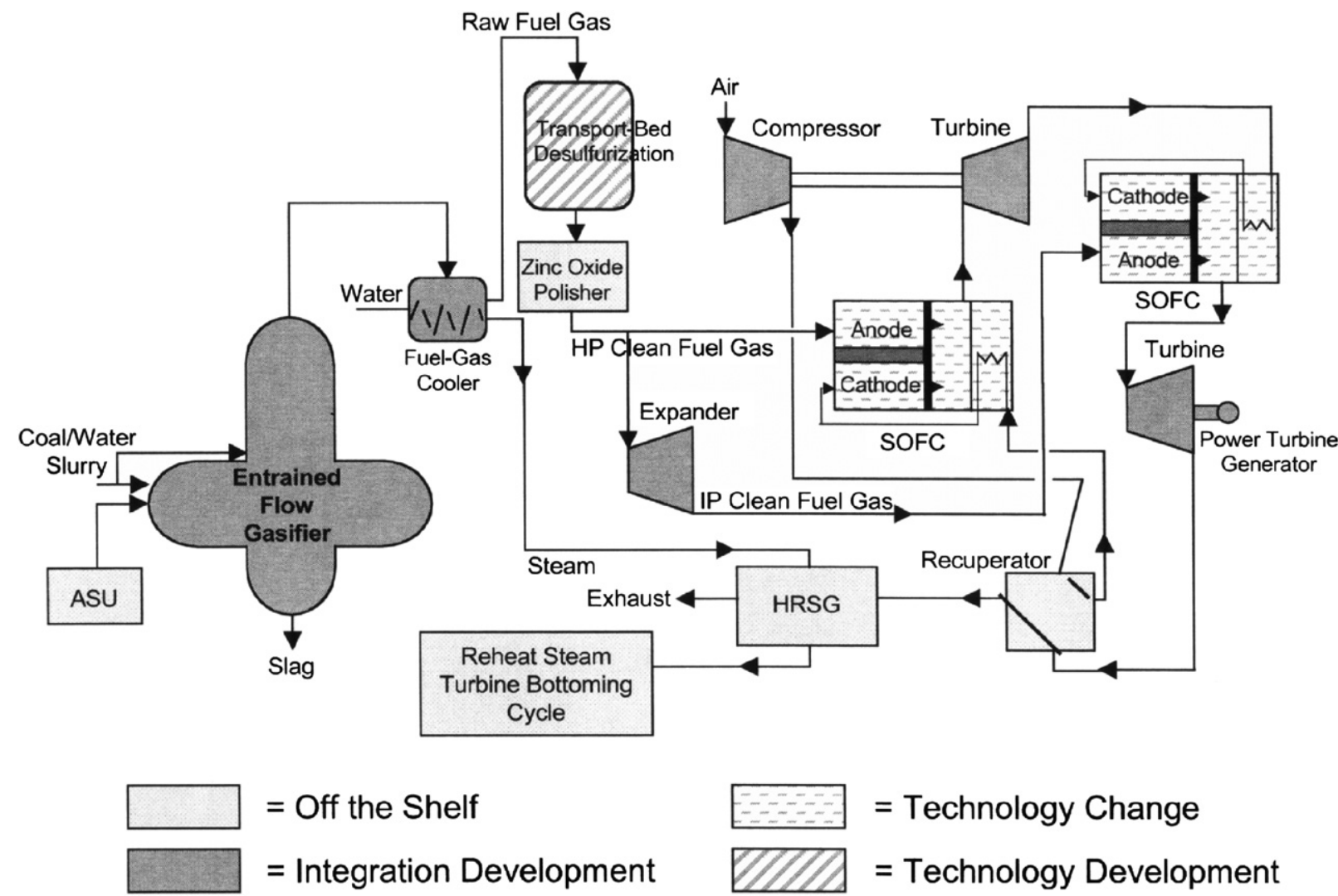

Fig. 23. Hybrid gasification fuel cell-gas turbine-steam CC [42]. 
and more expensive equipment, requiring more energy to operate. There is, however, significant cost and performance loss attached to the capture and compression of $\mathrm{CO}_{2}$ in preparation of its sequestration. Results of studies presented in Table 4 [43] provide information on estimates of total plant cost, cost of electricity and avoided cost of $\mathrm{CO}_{2}$ for different demonstrated IGCC and PC/USC technologies without and with $\mathrm{CO}_{2}$ capture and compression. The reference plant for "avoided cost of $\mathrm{CO}_{2}$ " calculations is the same plant without $\mathrm{CO}_{2}$ capture. If $\mathrm{PC} / \mathrm{USC}$ without capture is used as the reference plant, the numbers in the last row of Table 4 become: 28, 38.4, 37.5, 46.7 , and 42, respectively [62].

\subsection{Oxy-fuel combustion}

\subsubsection{PC oxy/FGR combustion with $C C S$}

There is great interest in $\mathrm{CO}_{2}$ capture capable coal combustion plants because of the increasing efficiency of SC plants, and the flexibility of PC and fluidized coal combustion for coal quality variation. The use of oxygen instead of air in combustion is the key to this problem.

When oxygen, instead of air, is used as oxidant in combustion, the mass flow rate of combustion products is significantly reduced with the consequence of increasing combustion temperature. By recirculating cooled combustion products, mainly $\mathrm{CO}_{2}$, from the end of the boiler to the furnace, the combustion products are diluted, and the flame temperature and furnace exit gas temperature can be restored to air combustion levels. For similar conditions of heat transfer in the combustion chamber, about $3 \mathrm{lbs}$ of flue gas has to be recirculated for every $\mathrm{lb}$ of flue gas produced, resulting in an $\mathrm{O}_{2}$ volume concentration of about
$30 \%$, compared to $21 \%$ for air-fired combustion. This difference is due to the higher specific heat of $\mathrm{CO}_{2}$ than that of the replaced nitrogen, and also, to $\mathrm{CO}_{2}$ 's high radiative emissivity at the flame's emission mean wavelength in the near-IR wavelength region [44].

Flue gas recirculation (FGR) increases the $\mathrm{CO}_{2}$ concentration in the flue gas to beyond $90 \%$ (the complement being $\mathrm{N}_{2}$ mainly due to air leakage and about $3 \% \mathrm{O}_{2}$ required for complete burn out of coal), making the flue gas ready for sequestration without energy intensive gas separation. It is possible that corrosion danger of the compressor and pipeline requires some post combustion gas clean up. In this case, the flow rate of the five-fold reduced flue gas volume through the post combustion mercury, particulates and sulfur emissions control plants leads to reduced capital and treatment costs. Boiler and flue gas treatment schematics for air fired and oxygen-fired operation, respectively, are shown in Fig. 24.

In the oxy/FGR system there is no need for $\mathrm{NO}_{x}$ selective catalytic reduction (SCR) because of the very low $\mathrm{NO}_{x}$ emissions due use of oxygen and flue gas recirculation in the combustion process.

\subsubsection{Reduction of $N O_{x}$ emission from oxy/FGR} combustion. The effective $\mathrm{NO}_{x}$ reduction with oxy/ FGR deserves special mention. The bulk of $\mathrm{NO}_{x}$ formed in coal combustion is due to the oxidation of fuel nitrogen. As the coal is injected into the flame it is dried and pyrolyzed, with a fraction of the organically bound "fuel N" evolving with the coal volatiles, and the rest remaining in the char. In the fuel-rich first stage of a two stage (rich-lean) combustion system, the fuel $\mathrm{N}$ evolved with the volatiles can be readily converted to molecular nitrogen. Nitrogen evolves from the char as the char

Table 4

Costs of different IGCC plants and USC/PC without and with $\mathrm{CO}_{2}$ capture [43]

\begin{tabular}{llllll}
\hline Technology & $\begin{array}{l}\text { IGCC Texaco } \\
\text { Quench }\end{array}$ & $\begin{array}{l}\text { IGCC Texaco } \\
\text { Radiant SGC }\end{array}$ & IGCC E-Gas & IGCC shell & $\begin{array}{l}\text { PC ultra } \\
\text { supercritical }\end{array}$ \\
\hline MW no capture & 512 & 550 & 520 & 530 & 600 \\
TPC \$/KW no capture & 1300 & 1550 & 1350 & 1650 & 1235 \\
COE \$/MWh no capture & 50.1 & 55.7 & 50.2 & 57.2 & 45.0 \\
MWwith capture & 455 & 485 & 440 & 465 & 460 \\
TPC \$/kW with capture & 1650 & 1950 & 68.9 & 2200 & 2150 \\
COE \$/MWh with capture & 62.7 & 69.6 & 29 & 29 & 76.2 \\
Avoided cost of $\mathrm{CO}_{2}$ \$/mt & 18 & 22 & 42 & 42 \\
\hline
\end{tabular}

450 MW net; Pittsburg \#8 bituminous coal; IGCCs with spare gasifiers. Other assumptions same as for Table 3. 


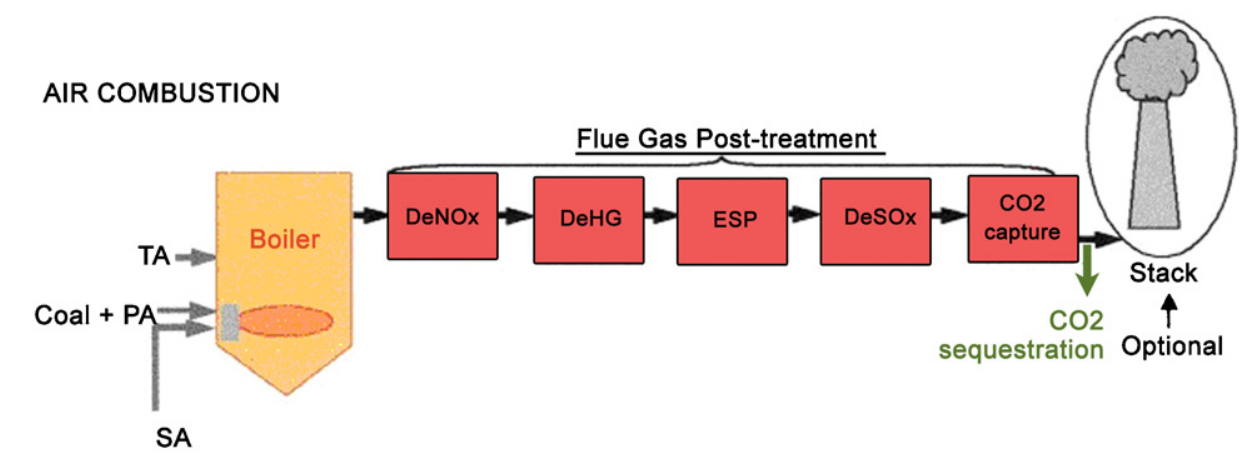

(a)

O2/FLUE GAS COMBUSTION

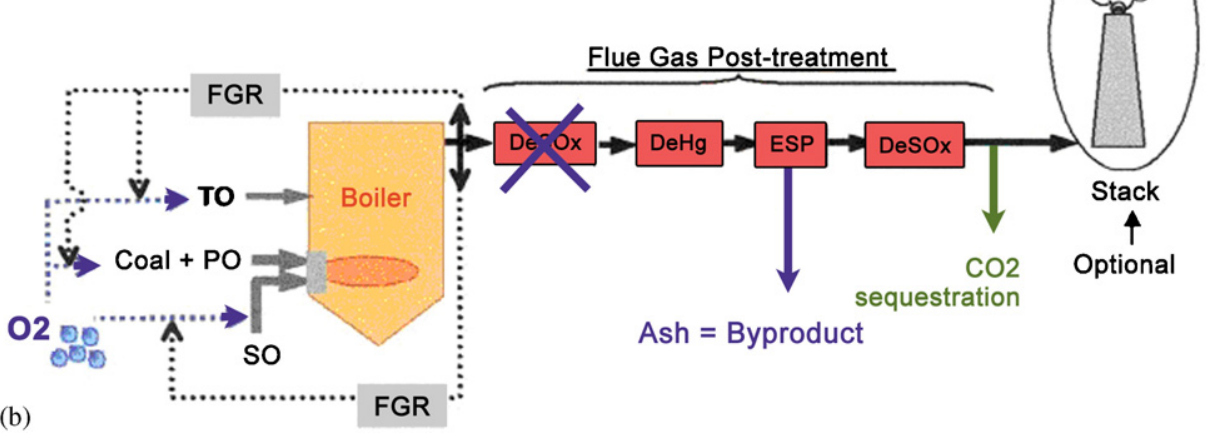

Fig. 24. Schematic of PC combustion (a) with air, and (b) with oxy-flue gas recirculation [45].

burns, and a fraction of the char nitrogen that is carried over to the fuel-lean stage of combustion is oxidized to $\mathrm{NO}_{x}[46,52]$.

In oxy/FGR combustion, due to the higher temperature of the early flame, a larger fraction of the coal mass evolves as volatile matter [48] which creates favorable conditions for the reduction of the fuel $\mathrm{N}$ to $\mathrm{N}_{2}$. Another factor leading to strongly reduced $\mathrm{NO}_{x}$ emission is " $\mathrm{NO}_{x}$ reburn", i.e., reaction of $\mathrm{NO}_{x}$ in the recirculated flue gas with hydrocarbon fragments in the volatile flame [47]. This reaction converts the recirculated $\mathrm{NO}_{x}$ to molecular nitrogen, $\mathrm{N}_{2}$, in the fuel-rich part of the flame. Results of pilot plant studies indicate that the $\mathrm{NO}_{x}$ emission from oxy-FGR combustion is sufficiently low to satisfy the tightest emission standards without SCR. There is, however, a caveat: as the rate of recirculation increases, the $\mathrm{NO}_{x}$ emission also increases [45]. This is because the lower flame temperature near the burner decreases the volatile yield and reduces also the conversion of fuel $\mathrm{N}$ to $\mathrm{N}_{2}$ [46].

4.2.1.2. Overall plant performance; retrofit and new plant. Croiset et al. [49] and Buhre et al. [50,51] provide comprehensive reviews of studies on oxy/ coal combustion. In most of these studies, $90 \%$ or more of the $\mathrm{CO}_{2}$ is captured producing a $98 \%$ pure $\mathrm{CO}_{2}$ stream. For retrofitting an existing subcritical steam PC plant, the data show the importance of the base plant efficiency. The air separation unit takes about $20 \%$, and the $\mathrm{CO}_{2}$ purification, compression-liquefaction $12-14 \%$ of the gross electricity output of the plant, representing about $1 / 3$ of the plant's output. The net plant efficiency with $\mathrm{CO}_{2}$ capture is between $23 \%$ and $26 \%$ (LHV) [53]. For retrofitting a higher efficiency supercritical PC plant, the energy penalty of $\mathrm{CO}_{2}$ capture is much lower: the total energy output of the plant is reduced by about $20 \%$ and conditions are even more favorable for new supercritical PC plant with a net efficiency of about 34\% (LHV) [54].

Among the issues to be resolved is the treatment of the recycle stream; should the $\mathrm{SO}_{2}$ be removed before recycle and should the recycle stream be dried? Unknown are also the purity requirements of the $\mathrm{CO}_{2}$ stream for sequestration. They are less demanding than those in IGCC for entry to the GT, and if the $\mathrm{SO}_{x}$ and $\mathrm{NO}_{x}$ could be sequestered along with $\mathrm{CO}_{2}$ in the geologic formation, the total dry 
flue gas of the PC/oxy plant could be prepared for compression, pipeline transportation and sequestration.

Another question concerns the heat balance between steam generation in the furnace by radiation, and superheating the steam mainly in the convection section of the boiler. As the mass flow rate of recirculated flue gas decreases, the furnace temperature rises and more steam is generated by radiation in the furnace section. Under the same conditions the heat transfer in the convective section decreases because of the reduced gas mass flow rate, causing the superheat temperature to drop. In new designs there is a possibility to place a larger part of the superheater into the furnace but for retrofit of existing plant the balancing would need to be done both by the control of the rate of flue gas recirculation and possibly also by shunting off excess steam before the superheater when necessary. The excess steam may be used in the ASU plant [54].

While laboratory scale experimental, and design studies show no major obstacles for oxy combustion, full-scale demonstration is needed before this promising technology can be deployed. Two $30 \mathrm{MWe}$ demonstration plants are under development, one in Europe by the Vattenfall utility company and the German VGB, and another in Brisbane Australia, conversion of an existing airblown $30 \mathrm{MWe}$ power plant to oxygen, supported by an Australian-Japanese consortium.

\subsubsection{CFBC with oxy/FGR}

Nskala et al. [55] show that CFBC with an external heat exchanger lends itself favorably to oxy/fuel application because the solids circulation provides an effective means, additional to flue gas recycle, for controlling the combustion temperature.
Solids, consisting of sorbent, coal ash and coal char particles, are precipitated from the gas stream exiting the combustor (riser) section of the CFB boiler and are split into two solids streams: one that is recirculated to the riser without cooling, and the other that is cooled in an external heat exchanger before recirculation. The cooling of the combustor by the cold solids permits the reduction of the rate of flue gas recirculation, with the result that the $\mathrm{O}_{2}$ concentration in the feed stream can rise to $60 \%$ without exceeding a limiting combustor temperature level of about $800{ }^{\circ} \mathrm{C}$ required by the thermodynamic stability of $\mathrm{CaSO}_{4}$ and by smooth fluidization. The corresponding lower gas mass flow leads to reduced size and cost of the boiler and, if needed, of the post combustion clean up plant.

\subsection{Chemical and thermal looping (in the DOE $R \& D$ portfolio)}

In chemical looping, an oxygen donor, usually a solid oxide such as $\mathrm{CaSO}_{4}$, is stripped of the oxygen by coal in a high-temperature endothermic reducer reactor to form $\mathrm{CaS}$, and the oxygen reacts with the coal to form $\mathrm{CO}, \mathrm{CO}_{2}$ and $\mathrm{H}_{2}$. The $\mathrm{CaS}$ is then transported to an exothermic oxidizer reactor, in which it is oxidized by air to form $\mathrm{CaSO}_{4}$. The calcium is cycled between the two reactors forming a "chemical loop", a coal gasification process without the need of an oxygen plant (Fig. 25) [56,57].

In order to speed up gasification reactions between two solids, the oxygen donor and the coal, a fraction of the product gas is recirculated, and a small amount of steam is injected into the reducer reactor.

\section{Consider the following Chemical loop:}

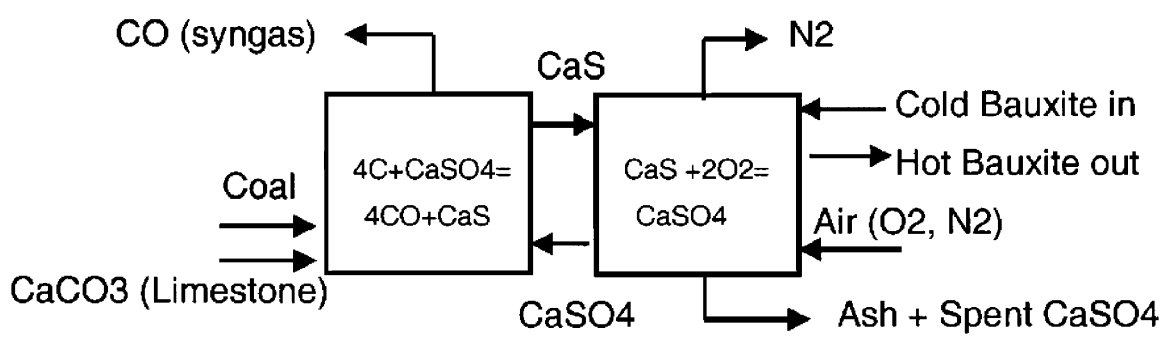

\section{CaS to CaSO4 chemical loop}

Fig. 25. Gasification of coal with $\mathrm{CaSO}_{4}$ as oxygen donor and oxidation of CaS with air to form $\mathrm{CaSO}_{4}[56,57]$. 
Additional chemical looping is used to calcine limestone, $\mathrm{CaCO}_{3}$, decomposing it to $\mathrm{CaO}$ and $\mathrm{CO}_{2}$ in one reactor, and transport $\mathrm{CaO}$ to another, where it captures $\mathrm{CO}_{2}$ from the syngas formed in the gasification process (Fig. 26).

To maintain the required temperature $\left(2000^{\circ} \mathrm{F}\right)$ for the gasification reactions and for the calcination of the limestone, thermal looping is used. This is a regenerative heat exchange process with pebbles of some mineral, e.g., bauxite. The pebbles are pneumatically transported and cycled between a high-temperature exothermic oxidizer-, and an endothermic reducer-reactor. The reactors are fluidized beds in which the oxygen donor minerals are carried over, and are separated from the gas stream by cyclone precipitators, while the larger heat exchanger pebbles are drained from the bottom of the bed.

Chemical looping is an advanced technology in its early development. Results of laboratory and pilot scale experimental studies on chemical looping gasification carried out under DOE sponsorship by ALSTOM and reported by Bozzuto et al. [58], and Marion et al. [59], show promise of successful development of this technology leading to demonstration stage within the next $10-15$ years. It is

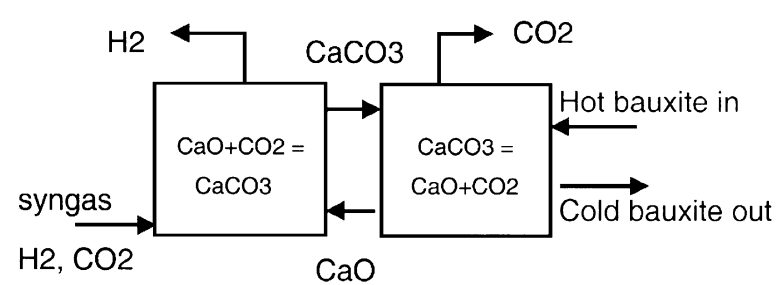

$\mathrm{CaO}$ to $\mathrm{CaCO} 3$ Chemical loop

Fig. 26. $\mathrm{CO}_{2}$ capture by $\mathrm{CaO}$ from syngas and $\mathrm{CaCO}_{3}$ calcination $[56,57]$. estimated that successful development to commercial stage of chemical looping gasification has the promise of IGCC plant efficiency improvement by about 2.5 percentage points, reductions in TPC by about $\$ 130$, and in COE by $\$ 3 / \mathrm{MWh}$, respectively.

\section{Efficiency, $\mathrm{CO}_{2}$ emissions and cost of clean coal power generation technologies}

Normalized information from several sources in the technical literature on the performance, efficiency and costs of advanced electric power generation technologies without and with CCS including $\mathrm{PC} / \mathrm{SC} /$ oxy with CCS are shown in Table 5 [60]. As can be seen, the slightly higher capital cost of more advanced, higher efficiency plant is compensated by fuel savings - even for inexpensive US coals - so that the COE is gradually reduced as the plant efficiency increases for plants both without and with CCS.

For plants with CCS, the efficiency of the underlying plant is important to reduce the energy penalty of $\mathrm{CO}_{2}$ capture and compression. The schematic in Fig. 27 illustrates the combination of the efficiency-, and zero emission-trajectories

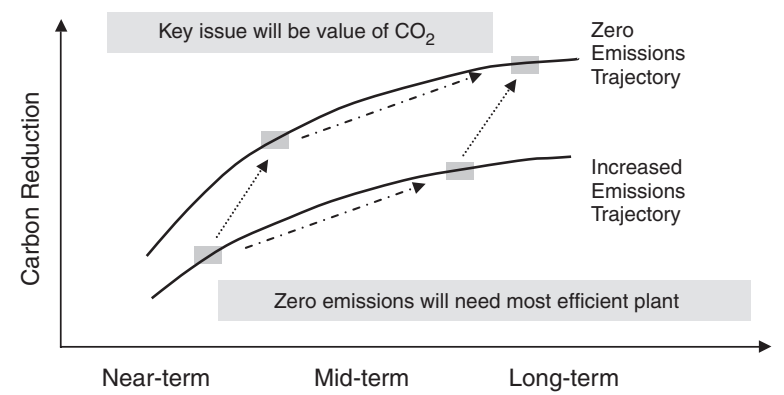

Fig. 27. Schematic of the combination of zero emission and efficiency trajectories leading to maximum emission control [61].

Table 5

$\mathrm{CO}_{2}$ emission, efficiency and costs of advanced power generation technologies without and with CCS [60]

\begin{tabular}{|c|c|c|c|c|c|c|c|c|c|}
\hline \multirow[t]{2}{*}{$\mathrm{CCS}$} & \multicolumn{2}{|c|}{ Subcritical } & \multicolumn{2}{|c|}{ Supercritical } & \multicolumn{2}{|c|}{ Ultra supercritical } & \multirow{2}{*}{$\begin{array}{l}\text { PC/oxy } \\
\text { With }\end{array}$} & \multicolumn{2}{|l|}{ IGCC } \\
\hline & Without & With & Without & With & Without & With & & Without & With \\
\hline Efficiency \% HHV & 34.3 & 25.1 & 38.5 & 29.3 & 43.4 & 34.1 & 30.6 & 38.4 & 31.2 \\
\hline $\mathrm{CO}_{2}$ emitted $\mathrm{g} / \mathrm{kWh}$ & 913 & 127 & 830 & 109 & 738 & 94 & 104 & 824 & 101 \\
\hline TCR $\$ / \mathrm{kW}$ & 1430 & 2500 & 1490 & 2400 & 1520 & 2340 & 2300 & 1600 & 2120 \\
\hline $\mathrm{COE} \mathrm{c/kWh}$ & 4.8 & 8.16 & 4.78 & 7.69 & 4.69 & 7.34 & 6.98 & 5.13 & 6.51 \\
\hline
\end{tabular}


as they are leading to maximum $\mathrm{CO}_{2}$ emissions reduction [61].

\section{Concluding remarks}

- Efficiency improvement is far the most predictable and lowest cost method to reduce all emissions including $\mathrm{CO}_{2}$.

- Power generation efficiency is steadily increasing with the development and continued deployment of advanced combustion and gasification technologies.

- The thermodynamic efficiency of power generation can be increased by the addition of heat to the cycle at increased pressure and temperature in both the Rankine cycle, and GT combined Brayton-Rankine cycles, enabled by the development of new, advanced materials in steam plants, and improved cooling technology, thermal barrier coatings, and new ceramic materials for structural parts of GTs.

- NG combined cycle plants are the highest efficiency, cleanest and lowest capital cost power plants, but the high and volatile price of $\mathrm{NG}$ makes them unattractive for base load operation.

- There is great interest in the continued development and application of clean coal technologies because of the secure and economic coal supply, and the capability of coal utilization technologies to comply with increasingly tight environmental controls.

- In addition to combustion process modifications and post combustion cleanup, the improving efficiency of combustion and gasification cycles are leading to significant reductions in pollutant and $\mathrm{CO}_{2}$ emissions.

- Presently available PC, CFB and IGCC plants have efficiencies of about 8 percentage points, or a relative $25 \%$ higher than the installed plant average, with correspondingly higher environmental performance.

- Reductions in emissions as a result of increased efficiency would become clearer if emissions were related to the output (per $\mathrm{kWh}$ or MWh) of the plant. The present system of input-based emission standards $\left(\mathrm{lb} / \mathrm{MBtu}\right.$ or $\left.\mathrm{g} / \mathrm{Nm}^{3}\right)$ hide the environmental advantage of efficiency and is not therefore conducive to the choice of advanced, high efficiency power plants.

- The "zero emission" coal plant of the future will include $\mathrm{CO}_{2}$ capture and compression for sequestration (CCS), a technology expected to come to fruition in the mid 2020s.
- Prior to the commercial application of CCS, the most cost effective way of reducing all emissions including $\mathrm{CO}_{2}$ from new coal-based power plants is to deploy plants with the highest efficiency commensurate with cost and availability.

- In the near term, the choice of coal-based generating technology without CCS is PC or CFBC in supercritical, or for PC also USC cycle. While IGCC has a smaller cost differential between no-capture and capture plant, IGCC without $\mathrm{CO}_{2}$ capture it is not presently competitive on cost and on availability with $\mathrm{PC}$ or CFBC plants.

- IGCC with CCS technology is likely to emerge as the eventual sustainable coal fuelled option; it has the advantage of providing the base for the future hybrid fuel cell/GT/steam coal plant with $60 \%$ cycle efficiency and near zero emission.

- The primary coal-based electricity generating technologies with $\mathrm{CO}_{2}$ capture (CCS) are IGCC with pre-combustion capture, PC with postcombustion capture, and oxy-fired PC or CFBC. Flue gas clean up for oxy combustion plant has to satisfy standards for compression, pipeline transportation and sequestration that are less stringent than those for GT entry in IGCC. The sequestration of the dry flue gas without $\mathrm{CO}_{2}$ separation could make oxy combustion in SC and USC steam plants competitive with IGCC.

- Additional to increased plant cost, $\mathrm{CO}_{2}$ capture involves significant performance and efficiency reduction, and it is essential therefore that the underlying plant efficiency be as high as possible.

- Cost comparisons of advanced coal-based power generating systems show that not withstanding the marginally higher first cost of higher efficiency plants, the COE and the output-based emissions are reduced as the efficiency increases in plants both without and with $\mathrm{CO}_{2}$ capture.

\section{Acknowledgments}

The author is grateful for valuable discussions and information received from Nancy Mohn, John Marion and Carl Bozzuto (Alstom), Neville Holt and Stu Dalton (EPRI), Adel Sarofim(University of Utah), Klaus Hein (University of Stuttgart) Jim Katzer, Gregory McRae, Howard Herzog, (MIT), in the course of writing this paper. Thanks are due to Don McGaffigan for his helpful assistance in the production of the manuscript and the illustrations in the paper. 


\section{References}

[1] Termuehlen H, Empsperger W. Clean and efficient coal fired power plants. New York: ASME Press; 2003.

[2] Schilling HD. VGB Kraftwerkstech 1993;73(8):564-76 (English ed.).

[3] Büki G. Magyar Energiatech 1998;6:33-42.

[4] Babcock, Wilcox. Steam - its generation and use. In: Schultz SC, Kitto JB, editors. 1992. p. 24-10.

[5] Henry JF, Fishburn JD, Perrin IJ, Scarlin B, Stamatelopoulos GN, Vanstone R. In: Proceedings of the 29th international conference on coal utilization and fuel systems, US DOE, ASME; 2004. p. 1028-42.

[6] Armor AF, Viswanathan R, Dalton SM. In: Proceedings of the 28th international conference on coal utilization and fuel systems, US DOE, ASME; 2003. p. 1426-38.

[7] Marion J. ALSTOM power, Private communication, 2005.

[8] Blum R, Hald J. ELSAM Skaerbaek Denmark, 2002.

[9] Kjaer S, Klauke F, Vanstone R, Zeijseink A, Weissinger G, Kristensen P, et al. Powergen Europe, Brussels, Belgium; 2001.

[10] Palkes M. Boiler materials for ultra supercritical coal power plants conceptual design ALSTOM approach, NETL-DOE, 2003, USC T-1.

[11] Booras G, Holt N. Pulverized coal and IGCC plant cost and performance estimates. In: Gasification technologies conference, Washington, DC; 2004.

[12] Chiesa P, Macchi E. Tans. ASME J Eng Gas Turbine Power 2004;126(4):770-85.

[13] Meisl J, Kapp K, Leuckel W, Wittig S. Forschungsberichte Verbrennungs Kraftmaschienen FVV, 1994.

[14] Frutschi HU. Gas turbines with sequential combustion for cogeneration of heat and power. ABB Review 1995/3.

[15] Hauenschild R, Imwinkel B. In: International joint power generation conference, Phoenix, AZ, VGB/ASME; 1994.

[16] Foster-Pegg RW. Westinghouse Electric Co Intersociety energy conversion conference, San Francisco, CA; 1984.

[17] Mannesmann Edelstahlrohr Gmbh, A high temperature corrosion resistant material of construction AC66(X5 NiCrNb3227). Report of public presentation, DuisbergHuckingen, Germany, March 1989.

[18] Seery D, Sangiovanni J. In: Proceedings of the advanced coal based power and environmental systems conference, Morgantown, PA, DOE FETC, 1998.

[19] Beér JM, Homola V. Innovative technological initiatives to upgrade power plants. In: IEA-USDOE-USAID international conference in clean coal utilization, Budapest, Hungary, 24-28 February 1992.

[20] Robson FL, Seery D. ASME paper no 94-JPGC-GT-6, 1994.

[21] Bose A, Bonk D, Fanand Z, Robertson A. In: Proceedings of the 29th international technical conference on coal utilization and fuel systems, US DOE, ASME; 2004. p. 624-33.

[22] Robertson A, Garland R, Newby R, Rehmat A, Rebow L. Second generation pressurized fluidized bed combustion plant. Foster Wheeler Dev. Corp. Report to the US DOE DE-AC-21-86MC21023, 1989.

[23] Beér JM, Garland RV. A coal fueled combustion turbine cogeneration system with topping combustion. Trans ASME J Eng Gas Turbines Power 1997;119(1):84-92.
[24] Penner SS, et al. Coal gasification: direct application and syntheses of chemicals and fuels. Energy 1987;12(8/9).

[25] Higman Ch, van der Burgt M. Gasification. Amsterdam: Elsevier; 2003.

[26] Phillips JN. I\&C needs of IGCC. In: Proceedings of the 48th annual ISA POWID symposium; 2005.

[27] Beér JM. Coal-water fuel combustion; fundamentals and application. A North American overview. In: Proceedings of the second European conference on coal liquid mixtures, London, England. I. Chem. E. Symposium Series no. 95; 1985.

[28] Beér JM, Vermes G. Gas Turbine combustor for coal-water slurries. In: Proceedings of the ASME engineering foundation conference on tomorrow's fuels, Santa Barbara, CA, 7-12 November 1982.

[29] Holt, N. In: Gasification technology conference, San Francisco, October 2004.

[30] The Stamet Pump, in clean coal today, Newsletter of the Office of Fossil Energy USDOE; DOE/FE-0486 Issue \#63; 2005.

[31] Reid WT. External corrosion and deposits, boilers and gas turbines. In: Beér JM, editor. Elsevier Fuel and Energy Science Monograph Series; 1971.

[32] Dolezal R. Schmelzfeuerungen, Theorie, Bau und Betrieb. Berlin: VEB Verlag Technik; 1954.

[33] Dolezal R. Large boiler furnaces. In: Beér JM, editor. Fuel and Energy Monograph Series. New York: Elsevier; 1967.

[34] Henderson C. Understanding coal fired power plant cycles. IEA CCC/91; 2004.

[35] Lovis M, Drdziok A, Witchow A. In: Proceedings of the Power-Gen Europe 1994; Penn Well, Utrecht The Netherlands, 1994. p. 327-49.

[36] Couch GR. OECD coal fired power generation. IEA Per/33, 1997.

[37] Holt N, Booras G, Todd D. In: The gasification technologies conference, San Francisco, CA, 2003.

[38] Dennis RA. The DOE FE turbine program, Presentation to NRC panel on DOE's IGCC R\&D Program, Washington, DC, October 2005.

[39] US National Research Council Panel on DOE's IGCC Program, Washington, DC, 2006.

[40] Haupt G, Karg J. The role of IGCC in advanced power generation. In: Power-Gen Asia'97, Singapore, Siemens Power Generation, September 1997.

[41] Wright TL. Coal gasification-back to the future? In: Proceedings of the 26th international technical conference on coal utilization and fuel systems, USDOE, 2003. p. $225-35$.

[42] Ruth LA. US DOE Vision21 Workshop, FETC Pittsburgh, PA, Dec. 1998.

[43] Holt N. Gasification process selection-trade-offs and ironies. In: Gasification technologies conference, Washington, DC, 2004.

[44] Hottel HC, Sarofim AF. Radiative heat transfer. New York: McGraw-Hill; 1967.

[45] Sangras R, Chatel-Pelage F, Pranda P, Farzan H, Vecci S, $\mathrm{Lu} \mathrm{Y}$. Oxy-combustion process in pulverized coal boilers; a promising technology for COP2 capture. In: Proceedings of the 29th international technical conference on coal utilization and fuel systems, Clearwater, FL, April 2004. 
[46] Goel SK, Beér JM, Sarofim AF. An emissions model for a bubbling FBC using detailed chemical kinetics: significance of destruction reactions. J Inst Energy 1996; LXIX (481).

[47] Wendt JOL, Streling CV. J Air Pollut Contr Assoc 1974;24: 1055.

[48] Howard JB. In: Elliott MA, editor. Chemistry of coal utilization, second supplimentary volume. New York: Wiley; 1981. p. 665-784.

[49] Croiset E, Thambimuthu KV. Coal combustion with flue gas recirculation for $\mathrm{CO}_{2}$ recovery. In: Riemer P, Eliassonand B, Wokaun A, editors. Greenhouse gas control technologies. Amsterdam: Elsevier Science Ltd.; 1999.

[50] Buhre BJP, Elliott LK, Sheng CD, Gupta RP, Wall TF. Oxy-fuel combustion technology for coal fired power generation. Prog Energy Combust Sci 2005;31(4):283-307.

[51] Khare S, Wall T, Gupta R, Elliott L, Buhre B. Retrofitting of air-fired PF plant to oxy-fuel: heat transfer impacts for the furnace and convective pass and associated oxygen production requirements. In: Proceedings of the fifth Asia-Pacific conference on combustion, Adalaide, July 2005.

[52] Beér JM. Low $\mathrm{NO}_{x}$ burners for boilers, furnaces and gas turbines; drive towards the lower bounds of $\mathrm{NO}_{x}$ emissions.In: Invited Lecture, third international conference on combustion technologies for a clean environment, Lisbon, Portugal, 1995; Combust Sci Tech V 1996; 121(1-6): 169.

[53] Anderson K, Birkstead H, Maksinen P, Johnsson F, Stroemberg L, Lyngfelt L. An $865 \mathrm{MW}$ lignite fired $\mathrm{CO}_{2}$ free power plant - technical feasibility study. In: Proceedings of the sixth conference on greenhouse gas control technologies (CHGT-6), Kyoto, Japan, 2002.

[54] Dillon DJ, Panesar RS, Wall RA, Allam RJ, White V, Gibbins $\mathrm{J}$, Haines MR. Oxy-combustion processes for $\mathrm{CO}_{2}$ capture from advanced supercritical PF and NGCC plant. In: Proceedings of the seventh conference on greenhouse gas control technologies (CHGT-7), Vancouver, BC, Canada, 2004.

[55] Nsakala L, et al. Greenhouse gas emissions control in circulating fluidized bed boilers. US DOE/NETL [48] Cooperative Agreement, May 2003.
[56] Moss G. The oxygen donor gsification process. In: Howard JR, editor. Fluidized beds combustion and applications. London and New York: Applied Science Publishers; 1983.

[57] Turek DG, Liljedahl GN, Nsakala ya Nsakala Andrus HE, Chiu JH. ALSTOM's development of advanced CFB based technologies for $\mathrm{CO}_{2}$ mitigation. In: Proceedings of the 30th international technical conference on coal utilization and fuel systems, Clearwater, FL, US DOE; 2005.

[58] Bozzuto C, Mohn N. Environmentally advanced clean coal plants. In: Proceedings of the 19th world energy congress, Sydney, Autralia, 6-9 September 2004.

[59] Marion J, Bozzuto C, Nsakala N, Lijedahl G. Evaluation of advanced coal combustion and gasification power plants with greenhouse gas emission control, topical phase 1. DOENETL Report no. DE-FC26-01NT41146, Prepared by ALSTOM, 2003.

[60] Deutch J, Moniz E. The future of coal in a greenhouse constrained world. MIT Report in preparation, 2006.

[61] Minchener A, McMullan J. A strategy for sustainable power generation from fossil fuels in Europe Energy World, May 2005. p. 18-21

[62] Booras G. EPRI, Private communication.

[63] Ackeret JK. Sweiz Bauseitg 1939;113:229.

[64] Mordell DL. Proc Inst Mech Eng 1955;169:163-80.

[65] Breault RW. Power system development facility transport gasifier operations. In: Proceedings of the 30th international technical conference on coal utilization and fuel systems, Clearwater, FL, USDOE; 2005.

[66] The US National Coal Council. Coal Related Greenhouse Gas Management Issues. Report to the Secretary of Energy, NCC, Washington, DC, May 2003.

[67] Phillips J. Integrated gasification combined cycles with $\mathrm{CO}_{2}$ capture. In: GCEP research symposium, Stanford University; 2005.

[68] Holt N. Coal based IGCC plants recent experience and lessons learned. In: Gasification technologies conference, 2005. 